Loyola University Chicago, School of Law

LAW eCommons

Faculty Publications \& Other Works

2021

God Is My Roommate? Tax Exemptions for Parsonages Yesterday, Today, and (if Constitutional) Tomorrow

Samuel D. Brunson

Loyola University Chicago School of Law, sbrunson@luc.edu

Follow this and additional works at: https://lawecommons.luc.edu/facpubs

Part of the First Amendment Commons, Religion Law Commons, and the Tax Law Commons

Recommended Citation

Samuel D. Brunson, God Is My Roommate? Tax Exemptions for Parsonages Yesterday, Today, and (If Constitutional) Tomorrow, 96 IND. L.J. 521 (2021).

This Article is brought to you for free and open access by LAW eCommons. It has been accepted for inclusion in Faculty Publications \& Other Works by an authorized administrator of LAW eCommons. For more information, please contact law-library@luc.edu. 


\title{
God Is My Roommate? Tax Exemptions for Parsonages Yesterday, Today, and (if Constitutional) Tomorrow
}

\author{
SAMUEL D. BRUNSON ${ }^{*}$
}

In 2019, the Seventh Circuit decided an Establishment Clause question that had been percolating through the courts for two decades. It held that the parsonage allowance, which permits "ministers of the gospel" to receive an untaxed housing allowance, does not violate the Establishment Clause of the Constitution. It grounded its conclusion in part on the "historical significance" test the Supreme Court established in its Town of Greece v. Galloway decision.

In coming to that conclusion, the Seventh Circuit cited a 200-year unbroken history of property tax exemptions for religious property. According to the Seventh Circuit, that history demonstrated that both the Founders and subsequent generations of Americans recognized that there was no constitutional problem with exempting parsonages.

The court's historical significance analysis was fundamentally flawed, however. Had the court actually engaged with this history, rather than made the conclusory assertion of consistent and uncontroversial exemption, it would have seen at least two things that complicated its facile conclusion. Significantly, in treating the history of religious property tax exemptions as unbroken and consistent, the court elided the actual history, which was messy and varied. The actual history provides no support for the proposition that the Framers and those who followed viewed property tax exemptions as constitutional.

Even if the history were as clean as the Seventh Circuit portrayed it, that history would have been irrelevant to the question of the constitutionality of the parsonage allowance. The Supreme Court did not incorporate the Establishment Clause against the states until 1947, so states faced no Establishment Clause bar to exempting for religious property. And the federal government only made four attempts at taxing property, none of which expressly exempted religious property.

In this Article, I explore the historical and current tax exemptions for parsonages, and trace how states arrived at their current exemptions. Ultimately, I conclude that the historical significance test, as applied by the Seventh Circuit, does not support the constitutionality of the parsonage allowance. I further conclude that, given its complexity and the fact that attorneys and judges tend to be poor historians, the historical significance test is not well suited as a jurisprudential tool for analyzing Establishment Clause questions, and that courts should not adopt it.

* Georgia Reithal Professor of Law, Loyola University Chicago School of Law. I would like to thank Ellen P. Aprill, Brian D. Galle, Adam Chodorow, Frederick M. Gedicks, James Hagy, David J. Herzig, and Jeffrey L. Kwall for their helpful comments. I would like to thank the Loyola University Chicago School of Law for its generous research stipend. I would also like to thank Jamie Brunson for her support. 


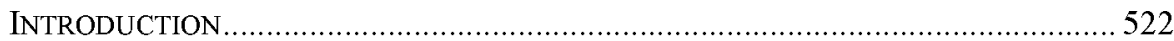

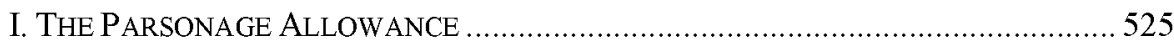

II. CONTROVERSY OVER THE PARSONAGE ALLOWANCE .......................................5 528

A. Challenge Number ONE: Rick WarRen AND ERWIn CHEMERINSKy. 531

B. Challenge Number Two: Freedom From Religion Foundation ... 532

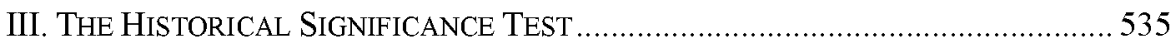

A. A (Brief) History of Religious Property Tax Exemptions .........536

1. AT THE TIME OF THE FRAMERS ….................................................537

2. RELIGIOUS PROPERTY TAXES AFTER THE FOUNDING ….................5540

IV. PROPERTY TAXES AND PARSONAGES........................................................... 542

A. CURRENT PRoperty TAX TREATMENT OF PARSONAGES .......................543

1. EXPLICIT EXEMPTIONS ............................................................ 543

2. NON-STATUTORY EXEMPTIONS FOR PARSONAGES ........................545

3. PARSONAGE EXEMPTION DEPENDS ON USE .................................547

4. PARSONAGES ARE Not EXEMPT …................................................549

5. ARE PARSONAGES EXEMPT? ……............................................... 550

B. Historic DifFERENCES IN THE TREATMENT OF PARSONAGES ............... 551

1. CONSTITUTIONAL CHANGE .................................................... 552

2. LegiSLATIVE CHANGE.................................................................. 554

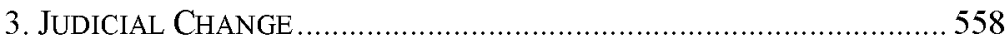

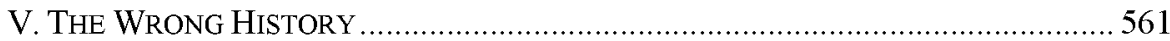

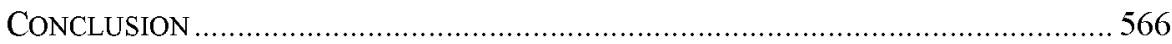

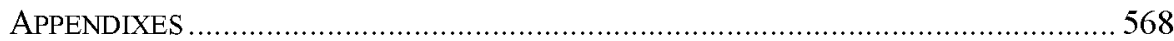

\section{INTRODUCTION}

The Fourth Presbyterian Church in Chicago bought a $\$ 975,000$ condominium for its head pastor in $2018 .{ }^{1}$ While expensive, that parsonage ${ }^{2}$ provides both the church and the pastor with substantial benefits. With employer-provided housing, the pastor does not need to pay for housing, and can instead spend her salary on other things, including food, housing, and even recreation. Meanwhile, the church can pay its pastor a lower salary because the pastor incurs lower expenses. In fact, as the Fourth Presbyterian Church considered acquiring the parsonage, its senior pastor agreed to a reduction in her cash compensation. ${ }^{3}$

1. Bob Goldsborough, Fourth Presbyterian Church Pays $\$ 975,000$ for Gold Coast Condo, Chic. TriB., (Aug. 1, 2018, 8:20 AM), https://www.chicagotribune.com/real-estate /elite-street/ct-re-elite-street-fourth-presbyterian-church-20180731-story.html [https://perma .cc/ZRL7-HXZK].

2. Broadly speaking, a "parsonage" is "the residence of any minister of religion." Parsonage, OXFORD ENGLISH DICTIONARY (3d ed. 2005). Because section 107 of the Internal Revenue Code is titled "Rental value of parsonages," however, I will use "parsonage" more broadly, meaning any housing provided to clergy. I.R.C. $§ 107$ (2018). While section 107 only excludes housing provided to a "minister of the gospel," the IRS reads "minister of the gospel" to include non-Christians whose duties "constitute the conduct of religious worship or the ministration of sacerdotal functions." Rev. Rul. 58-221, 1958-1 C.B. 53.

3. Senior Pastor Housing Proposal: Synopsis, Fourth Presbyterian Church (Apr. 12, 
This parsonage also provides the church and the pastor with less-obvious tax benefits. For instance, as long as the Fourth Presbyterian Church requires its head pastor to live in the parsonage as a condition of her employment, it will not have to pay Illinois property tax on the parsonage. And while employer-provided housing represents a benefit to an employee, clergy do not have to include the value of church-provided parsonages in their gross income for income tax purposes. The value of the parsonage to the pastor is higher than the after-tax amount other taxpayers would spend on similar housing.

While the Fourth Presbyterian Church has the resources to acquire a parsonage for its head pastor, ${ }^{4}$ those resources are unnecessary for clergy to receive the benefit of a federal income tax exemption for housing. Congress also allows clergy to receive a tax-free cash housing allowance, a benefit unavailable to nonclergy taxpayers These exclusions do not represent a policy of absolutely ignoring clergy housing for tax purposes: clergy have to include the value of church-provided housing and housing allowances in calculating their self-employment tax. ${ }^{5}$

The tax law treats (some) religious employees better than it treats nonreligious employees. This better treatment at least implicates the Establishment Clause. ${ }^{6}$ The Freedom From Religion Foundation noticed this implication, and twice filed suit, arguing that the parsonage allowance violated the Establishment Clause, culminating in the Seventh Circuit's decision in Gaylor v. Mnuchin?

The court faced a significant obstacle in adjudicating this case, though: the state of Establishment Clause jurisprudence "is a mess - both hopelessly confused and

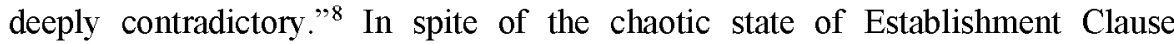
jurisprudence, the Seventh Circuit had to resolve the question of whether the parsonage allowance violated the Constitution. To do so, it independently applied two tests: "the test announced in Lemon v. Kurtzman ... and the 'historical significance' test of Town of Greece v. Galloway."

Although the Gaylor court uses two tests to bolster its holding, this Article will focus on the historical significance test adopted by the court. I focus solely on the historical significance test precisely because, unlike the Lemon test, it is new and has not been fleshed out. The Seventh Circuit's use of the test demonstrates both flaws

2018), $\quad$ https://www. fourthchurch.org/news/senior-pastor-housing-synopsis. html [https://perma.cc/SX7C-BJDU].

4. Because the Fourth Presbyterian Church has not posted its 2018 financial statements online, the public cannot know the value of its assets. It has disclosed its 2018 revenue though: in 2018 it brought in $\$ 8,220,652$. Fourth Presbyterian Church, 2018 Impact RePOrt, https://www.fourthchurch.org/giving/impact-2018.pdf [https://perma.cc/Z98F-PSY4].

5. Treas. Reg. \& 1.1402(a)-11(a) (2015).

6. See Christopher L. Eisgruber \& Lawrence G. Sager, Why the Religious Freedom Restoration Act is Unconstitutional, 69 N.Y.U. L. REv. 437, 448 (1994) ("[T] he idea of a broad privilege for religiously motivated conduct baldly contradicts the best understanding of the foundations of religious freedom.").

7. 278 F. Supp. 3d 1081, 1084 (W.D. Wis. 2017), rev'd, 919 F.3d 420 (7th Cir. 2019) ("This is the second time that the foundation and its officers have challenged $\S 107(2)$."). For a discussion of the Freedom From Religion Foundation's suits, see infra Section II.B.

8. Steven G. Gey, Reconciling the Supreme Court's Four Establishment Clauses, 8 U. PA. J. CONST. L. 725, 725 (2006).

9. Gaylor, 919 F.3d 420, 426-27 (7th Cir. 2019). 
in the test and significant difficulties courts can face in both choosing the appropriate history to explore and in actually evaluating that history.

I will demonstrate that the Seventh Circuit's application of the historical significance test was deeply flawed and ahistorical. The Seventh Circuit misrepresented the substantive history of the property tax exemption for parsonages. Even if it accurately portrayed the history, though, it chose the wrong history to focus on: property tax exemptions are not equivalent to income tax exemptions, either as a matter of law or as a matter of constitutional analysis.

In its Gaylor decision, the Seventh Circuit explains that questions of establishment must "acknowledge a practice that was accepted by the Framers and has withstood the critical scrutiny of time and political change." 10 Under this test, if the practice existed at the time the First Amendment was enacted and has continued to be accepted, a court should hesitate to find it unconstitutional. For questions of income tax, applying this test is incoherent, given that the income tax did not exist at the time of the Framers, ${ }^{11}$ and that the provision being challenged-the exclusion of cash housing allowances-was not enacted until $1954 .^{12}$

Instead of analyzing the history of the parsonage allowance, the Gaylor court looked at "a lengthy tradition of tax exemptions for religion, particularly for churchowned properties." 13 Using the property tax to analyze an income tax provision is problematic for a number of reasons, ${ }^{14}$ but even on its own terms, the Seventh Circuit's review of the history is both facile and inaccurate. Instead of engaging the relevant long and complex history, the Seventh Circuit provides a cursory summary in a single page of its opinion. In this Article, I will discuss both the federal parsonage allowance and state property tax exemptions for parsonages. In that discussion, I will highlight the shortcomings of the Seventh Circuit's use of the historical significance test, which reads the history in a motivated and instrumental manner to arrive at the conclusion it wants.

This Article proceeds as follows: In Part I, I discuss the parsonage allowance. I describe why and how Congress enacted it. Then, in Part II, I talk about two constitutional challenges that the parsonage allowance faced. Through legislation, Congress managed to protect the parsonage allowance from the first Establishment

10. Id. at 436 (quoting Town of Greece v. Galloway, 572 U.S. 565, 577 (2014)).

11. The modern income tax can trace its roots back to the British income tax of 1799 . Peter Harris, Income Tax in Common Law Jurisdictions: From the Origins to 18201 (2006). The United States enacted its first income tax during the Civil War, STEVEN A. BANK, KIRK J. STARK \& Joseph J. Thorndike, War and TaXes 39 (Kathleen Courrier et al. eds., 2008), but that tax expired in 1871. Samuel D. Brunson, Mormon Profit: Brigham Young, Tithing, and the Bureau of Internal Revenue, 2019 BYU L. REv. 41, 104 (2019). Congress made an abortive attempt to enact a federal income tax in 1894, David J. Herzig \& Samuel D. Brunson, Let Prophets Be (Non) Profits, 52 WAKE FoREST L. REv. 1111, 1122 (2017), and finally enacted the modern federal income tax in 1913. BANK ET AL., supra, at 11.

12. See infra notes 35-36 and accompanying text.

13. Gaylor, 919 F.3d at 436.

14. Among other things, the two are significantly different economically. "A major difference between a property tax and an income tax is that the latter taxes human capital (or at least returns there from) whereas the former does not (at least not directly)." HARRIS, supra note 11 , at 386 . 
Clause challenge, while, in the second, the Seventh Circuit ultimately held that the parsonage allowance was consistent with the Lemon test and that it met the Supreme Court's historical significance test.

Part III begins to engage with the historical significance test on a broad level. Rather than focus on parsonages, Part III looks at the history of religious property tax exemptions at the time of the Framers through the nineteenth century. The Part points out that the Establishment Clause is largely irrelevant to property tax exemptions for religious property. Notably, as the Establishment Clause was not incorporated against the states until 1947, this treatment is largely irrelevant to both the question of parsonage exemptions and to questions of religious property tax exemptions broadly. ${ }^{15}$ Nonetheless, because the Seventh Circuit fails to note any of this history, the Part will review these histories.

Part IV provides a comprehensive look at how states treat parsonages for purposes of their property tax both today and in the past. Currently, some states explicitly exempt parsonages, some include parsonages as a subset of exempt religious property, and some states do not exempt parsonages. Moreover, a number of states that currently exempt parsonages did not exempt them in the nineteenth or early twentieth centuries. Part IV analyzes the states that have changed their exemption.

All of this discussion will demonstrate that the history of property tax exemptions for parsonages is neither clean nor consistent and lends no support to the constitutionality of the parsonage allowance. Part V takes the analysis a step further, explaining why, even if the history was clean and consistent, it is irrelevant to the question of whether the parsonage allowance comports with the Establishment Clause.

Part V then explains that even if this history did support the proposition that property tax exemptions for parsonages met the historical significance test, that lends no support to the parsonage allowance's constitutionality. By looking at the property tax, the court chose an inapposite comparison. The differences between property tax exemptions and income tax exclusions differ in a constitutionally relevant manner.

Finally, the Conclusion will evaluate what this history means, not only for the Seventh Circuit's opinion in Gaylor, but also for the utility of the historical significance test. Ultimately, I conclude that the Gaylor opinion's application of the historical significance is a master class in misreading and misusing history. And that master class has significance beyond merely the analysis of the constitutionality of the parsonage allowance. It illustrates the difficulty in honestly evaluating a complicated history, and the pitfalls that attorneys and courts trying to do so face.

\section{The Parsonage Allowance}

In 1913, Congress enacted the modern federal income tax. ${ }^{16}$ This new tax applied to taxpayers" "entire net income arising or accruing from all sources in the preceding

15. See infra note 135 and accompanying text.

16. Joseph J. Thorndike, Their Fair Share: TAXing the Rich in the Age of FDR 5 (2013). 
calendar year to every citizen of the United States." 17 The law defined "income" broadly, including any compensation for services "in whatever form paid." 18

While this definition of income could potentially encompass virtually any type of transfer of value from an employer to an employee, Congress was not explicit about what had to be treated as income. For instance, the Revenue Act of 1913 did not explicitly mention employer-provided housing. ${ }^{19}$ The Treasury Department broadly believed that, in the abstract, such housing constituted a form of compensation and was thus subject to taxation. ${ }^{20}$ Still, within the first decade of the income tax, the Treasury Department began to cabin the reach of this broad rule.

In 1919, the Treasury Department announced that "[b] oard and lodging furnished seamen in addition to their cash compensation is held to be supplied for the convenience of the employer and the value thereof is not required to be reported in such employees" income tax returns." 21 It proceeded to formalize this test in regulations, providing that where an employer provided housing to its employees "for the convenience of the employer" rather than for compensatory purposes, employees could exclude the value of housing from their taxable income. ${ }^{22}$

Almost immediately after issuing the regulation, the Bureau of Internal Revenue began to provide examples of housing that met the "convenience of the employer" test. ${ }^{23}$ For instance, employees engaged in fishing and cannery work could receive tax-free housing where such housing was "necessary" as a result of the "location and nature" of their work. ${ }^{24}$ Similarly, where hospital employees were "subject to immediate service on demand at any time," and were thus required to accept housing from the hospital, they could exclude the value of that housing from their gross income. ${ }^{25}$ Employees of the Indian Service could also exempt employer-provided housing where the housing was provided for the convenience of the employer. ${ }^{26}$

While the Bureau's rulings did not represent an exclusive list of professions that qualified for the convenience-of-the-employer exception, it did provide that certain professions never qualified for tax-free housing under the convenience-of-theemployer test. In 1921, Treasury determined that clergy was one of these disqualified

17. Revenue Act of 1913, Pub. L. No. 63-16, § II(A)(1), 38 Stat. 114, 166.

18. Id. $\S \mathrm{II}(\mathrm{B})$ at 167.

19. Adam Chodorow, The Parsonage Exemption, 51 U.C. DAvIS L. REv. 849, 856 (2018).

20. See T.D. $2992,1920-2$ C.B. 76 ("[W]here a person receives as compensation for services rendered a salary and in addition thereto living quarters, the value to such person of the quarters furnished constitutes income subject to tax.").

21. O.D. $265,1919-1$ C.B. 71.

22. T.D. 2992, 1920-2 C.B. 76.

23. Samuel D. Brunson, God and the IRS: Accommodating Religious Practice in UNITED STATES TAX LAW 80 (2018).

24. O.D. $814,1921-4$ C.B. $84-85$.

25. O.D. $915,1921-4$ C.B. $84-85$.

26. O.D. 914, 1921-4 C.B. 85. Interestingly, for Indian Service employees, the convenience-of-the-employer test turned on whether the housing was "charged to the appropriation from which the compensation of such employees is paid," in which case they had to include it in their income. $I d$. On the other hand, if they were permitted to stay there "without making the right to use such quarters a part of the compensation of such employees," they did not. $I d$. 
professions. ${ }^{27}$ According to the Bureau ruling, if, in addition to receiving a salary, clergy "is permitted to use the parsonage for living quarters free of charge," they had to include the fair rental value of the parsonage in income. ${ }^{28}$

That same year, Congress overruled the Bureau of Internal Revenue. ${ }^{29}$ Congress did not merely enact a legislative mandate that parsonages fell within the Treasurycreated convenience-of-the-employer test. Rather, it created a new statutory category of exemption, allowing clergy to exclude " $[t]$ he rental value of a dwelling house and appurtenances thereof furnished to a minister of the gospel as part of his compensation." ${ }^{30}$ For clergy, Congress had introduced a brand-new exemption that allowed them to exclude housing provided for expressly compensatory purposes.

Within two years, the Bureau received questions about the scope of the exclusion: Did it also exclude housing allowances paid to clergy in place of parsonages? ${ }^{31}$ The Bureau replied that the exclusion applied only to the in-kind provision of housing; clergy had to include a housing allowance in gross income "as additional compensation for services rendered." ${ }^{32}$ In spite of the plain language of the parsonage allowance, a number of courts disagreed with the Bureau, holding that the parsonage allowance allowed clergy to exclude cash housing allowances from gross income. ${ }^{33}$ The Eighth Circuit justified its conclusion, not based on the text of the statute, but based on its conviction that "it was not the intent nor purpose of Congress that a house allowance in lieu of the rental value of a dwelling house and appurtenances thereof furnished to a minister of the gospel should be included in his gross income." $" 34$

In 1954, Congress stepped into this debate and sided with the judiciary. Congress added a provision to the tax law expressly excluding "the rental allowance paid to [a minister of the gospel] as part of his compensation to the extent used by him to rent or provide a home" from gross income. ${ }^{35}$ Representative Peter Mack, Jr., who introduced the provision, explained that a Baptist organization had alerted him to the tax disparity between clergy who received in-kind housing and clergy who did not, a disparity that he considered discriminatory. ${ }^{36}$

27. BRUNSON, supra note 23 , at 80 .

28. O.D. 862, 1921-4 C.B. 85. Clergy were not the only profession barred from excluding housing under the convenience-of-the-employer test: Army officers could not exclude in-kind housing or cash housing allowances from their gross income. O.D. 921, 1921-4 C.B. 86.

29. Chodorow, supra note 19 , at 857.

30. Revenue Act of 1921, Pub. L. No. 67-98, § 213(b)(11), 42 Stat. 227, 239 (1921).

31. I.T. 1694, II-1 C.B. 79 (1923).

32. Id.

33. BRUNSON, supra note 23, at 81.

34. Williamson v. Comm'r, 224 F.2d 377, 381 (8th Cir. 1955).

35. Internal Revenue Code of 1954, Pub. L. No. 83-591, § 107(2), 68A Stat. 1, 32.

36. BRUNSON, supra note 23 , at 81 . While Representative Mack stated that his primary goal was to end interdenominational discrimination, he also believed that benefiting clergy, who were "carrying on such a courageous fight" against a "godless and antireligious world movement," was "not too much to do for these people who are caring for our spiritual welfare." General Revenue Revision: Hearings on Forty Topics Pertaining to the General Revisions of the Internal Revenue Code Before the H. Comm. On Ways \& Means, 83d Cong. 1574-76 (1953) (statement of Rep. Peter F. Mack, Jr.). 
At the same time as it expanded the parsonage allowance, Congress codified the Treasury Department's convenience-of-the-employer test. ${ }^{37}$ Unlike the parsonage allowance, though, Congress provided no expansion in scope for this income exclusion. For an employee to exclude employer-provided housing from gross income, the employer had to provide in-kind housing, the housing had to be located on the business premises of and provided for the convenience of the employer, and the employee had to be required to accept the housing as a condition of her employment. $^{38}$

\section{CONTRoversy over the Parsonage AllowanCE}

Until recently, the parsonage allowance has faced only a limited amount of constitutional controversy. Almost two decades after the expansion of the exclusion to ministers' cash housing allowances, Professor David C. Johnson first noted that, even "[i]gnoring the constitutional problem" with the parsonage allowance, it seemed unfair. ${ }^{39}$ The next year, a comment in the Georgetown Law Journal not only argued that the parsonage allowance was unfair, but expressly argued that it violated the Establishment Clause of the Constitution. ${ }^{40}$

Since then, the pushback against the parsonage allowance has steadily grown. This pushback has not been limited solely to academics. For example, in 1984, to fulfill his promise to simplify the tax law, President Ronald Reagan "asked the Treasury Department to devise a tax reform plan." ${ }^{11}$ As part of its plan, the Treasury Department proposed eliminating the parsonage allowance. ${ }^{42}$ It explained that the parsonage allowance violated tax policy by allowing ministers to pay less in taxes, while putting upward pressure on marginal tax rates. ${ }^{43}$ Moreover, it was unnecessary: although clergy salaries were low compared to other professions, they were not low "compared to taxpayers in general." 44 And the exclusion disproportionately benefitted wealthy clergy. ${ }^{45}$

Still, academics have continued to contest the propriety of the parsonage allowance. While it would be beyond the scope of this Article to review all of the

37. Internal Revenue Code of 1954, Pub. L. No. 83-591, § 119, 68A Stat. 1, 39 (1954).

38. Id.

39. David C. Johnson, Provisions of the Tax Policy Review Bill of 1972 Affecting Individual Taxpayers, 49 N.D. L. REV. 439, 482 (1973). The unfairness Professor Johnson pointed out was that ministers were not in the only profession that was undercompensated. Id. The justification for subsidizing their homes would have to rest on some other grounds.

40. Roger H. Taft, Tax Benefits for the Clergy: The Unconstitutionality of Section 107, 62 GEO. L.J. 1261, 1271 (1974).

41. Matthew W. Foster, Note, The Parsonage Allowance Exclusion: Past, Present, and Future, 44 VAND. L. REV. 149, 162 (1991).

42. OfF. of the Sec'y Dept. of the Treasury, TAX Reform For Fairness, Simplicity, and Economic Growth: The Treasury Dep't Report to the President Overview 73 (1984).

43. Office of the Secretary of the Treasury, Tax Reform for Fairness, Simplicity, and ECONOMiC Growth: The TrEasury DeP'T Report to the President vol. 2 49 (1984).

44. Id.

45. $I d$. 
academic literature, I will summarize some of the commentary. In the early 1990s, Professor Joel Newman explained that "[s]ection 107 [the Code section excluding parsonages from income] has never made any sense. Legislative history is sparse and suggests only that Congress thought that ministers deserved a tax break." $46 \mathrm{He}$ highlighted two problems with it. The first was its questionable constitutionality. ${ }^{47}$ The second was its general unfairness. At religious universities, he explained, some faculty who fell outside of the scope of intended beneficiaries - including "members of the education and chemistry departments, as well as members of the religion department"-could qualify for tax-free parsonage allowances. ${ }^{48}$

In the early $2000 \mathrm{~s}$, Professor Edward Zelinksy complicated the analysis. Under the Supreme Court's Texas Monthly ${ }^{49}$ precedent, he said, the parsonage allowance would be unconstitutional "on the ground that section 107 narrowly subsidizes religion." ${ }^{50}$ Under its $\mathrm{Walz}^{51}$ precedent, on the other hand, Professor Zelinksy believed that the parsonage allowance would be "constitutional as a permissible recognition of sectarian autonomy." ${ }^{52}$ While he recognized the conflict and the argument that the parsonage allowance was unconstitutional, Professor Zelinksy ultimately thought that the Walz precedent - which would uphold the parsonage allowance-provided the better constitutional analysis. ${ }^{53}$ Still, although he believed that Walz provided the better analysis, he acknowledged that Texas Monthly was, at the time, the Supreme Court's last word on the question of subsidizing religion. ${ }^{54}$

A decade later, Professor Zelinsky continued to argue that the Establishment Clause permitted the government to exempt housing allowances paid to clergy from the tax base. ${ }^{55}$ By then, he had refined his argument to focus on avoiding entanglement between the state and religion. ${ }^{56}$ But, he argued, even if the parsonage allowance was permissible (though not mandatory), it represented poor tax policy:

46. Joel S. Newman, On Section 107's Worst Feature: The Teacher-Preacher, 61 TAX NOTES 1505, 1507 (1993).

47. Id. ("[T]he constitutionality of the section is not entirely clear.").

48. Id.

49. Texas Monthly, Inc. v. Bullock, 489 U.S. 1 (1989).

50. Edward A. Zelinksy, Dr. Warren, the Parsonage Exclusion, and the First Amendment, 95 TAX NOTES 115, 118 (2002).

51. Walz v. Tax Comm'n, 397 U.S. 664 (1970).

52. Zelinksy, supra note 50, at 118.

53. Id. at 120 .

54. Id. Subsequent to his article, Congress made some minor changes to prevent the Ninth Circuit from ruling on the constitutionality of the parsonage allowance. See infra text accompanying notes 78-80. After those changes, Professor Zelinsky acknowledged that "the recent amendment of section 107(2), while intended to bolster that provision, in my judgment weakens both the constitutional and the tax policy arguments for that section by enmeshing the clergy and the IRS for future years in potentially contentious controversies about the rental values of the homes of taxpayer/clergymen." Edward A. Zelinsky, Dr. Warren, Section 107, and Texas Monthly: A Reply, 95 TAX Notes 1663, 1669 n.54 (2002).

55. Edward A. Zelinsky, Do Religious Exemptions Entangle in Violation of the Establishment Clause? The Constitutionality of the Parsonage Allowance Exclusion and the Religious Exemptions of the Individual Health Care Mandate and the FICA and SelfEmployment Taxes, 33 CARDOzo L. REV. 101, 144 (2012).

56. Id. 
"In terms of tax policy, there is no persuasive case for Section 107(2) and its exclusion of cash parsonage allowances." 57

Around the same time, Professor Ellen Aprill suggested that the parsonage allowance be both expanded and narrowed so that it apply not to "ministers of the gospel," but to certain employees of all nonprofits who needed to be available for emergency calls. ${ }^{58}$ Doing so would avoid any potential Establishment Clause problem because clergy would make up a portion of a larger group that benefited rather than being the sole recipients of the benefit. ${ }^{59}$

More recently, in the course of the Seventh Circuit litigation, the Becket Fund for Religious Liberty argued that a tax-free housing allowance paid to clergy did not violate the Establishment Clause because it sent "a message of neutrality with respect to religion, not endorsement." ${ }^{60}$ Becket asserted that the parsonage allowance was merely the extension of a series of expansions to the convenience-of-the-employer test. ${ }^{61}$

Professor Adam Chodorow responded to Becket's assertion, arguing that the parsonage allowance raised significant Establishment Clause concerns because it "singles out religious actors for a special tax benefit ..." W2 While he acknowledged that Establishment Clause jurisprudence was "muddled," he argued, contrary to Professor Zelinsky, that the parsonage allowance did not fit within a broad, neutral policy that included clergy. ${ }^{63}$ As a result, he said, Walz was inapplicable, and courts should find the parsonage allowance unconstitutional under Texas Monthly. ${ }^{64}$

Despite the pushback against the parsonage allowance, no taxpayer challenged its constitutionality in court until the early 2000s. The author of the Georgetown Law Journal Comment argued that this failure to raise a constitutional challenge "can be credited in part to the fact that before the 1968 Supreme Court decision in Flast $v$. Cohen, a federal taxpayer qua taxpayer had no standing to challenge the constitutionality of a federal statute." 65 Even with this taxpayer standing, though,

57. Id. at 133 .

58. Ellen Aprill, Parsonage and Tax Policy: Rethinking the Exclusion, 38 EXEMPT ORG. TAX ReV. 29, 31 (2002).

59. Id.

60. Brief of Intervening Defendants-Appellants at 53, Gaylor v. Mnuchin, 919 F.3d 420, 425 (7th Cir. 2019).

61. Id.

62. Adam Chodorow, The Parsonage Exemption, 51 U.C. DAvIS L. REv. 849, 909 (2018).

63. Id.

64. Id.

65. Taft, supra note 40, at 1271. In 1923, the Supreme Court held that an individual's status as a taxpayer, by itself, did not confer standing to challenge the constitutionality of a statute. Commonwealth of Mass. v. Mellon, 262 U.S. 447, 487 (1923). Forty-five years later, the Court acknowledged that its holding had functioned as "an impenetrable barrier to suits against Acts of Congress brought by individuals who can assert only the interest of federal taxpayers. Flast v. Cohen, 392 U.S. 83, 85 (1968). The Court thus announced a new test under which an individual "sometimes has standing to challenge legislation solely as a result of her status as a taxpayer." Samuel D. Brunson, Dear IRS, It Is Time to Enforce the Campaigning Prohibition. Even Against Churches, 87 U. Colo. L. Rev. 143, 162 (2016). 
taxpayers have a hard time challenging the constitutionality of a tax provision. The pathway to challenge a tax law is remarkably narrow. ${ }^{66}$

Still, the author of the Comment predicted that the new standard enunciated in Flast would open the door for a constitutional challenge to the parsonage allowance. ${ }^{67}$ That predicted challenge materialized in $2002 .{ }^{68}$

\section{A. Challenge Number One: Rick Warren and Erwin Chemerinsky}

The first constitutional challenge to the parsonage allowance arose accidentally, the unintended consequence of a standard audit. The controversy started in the 1990s, when the IRS disallowed a portion of the Warrens' parsonage allowance exclusion. ${ }^{69}$ Richard Warren had founded the Saddleback Valley Community Church in $1980 .^{70}$ In 1992, the Warrens bought a house for $\$ 360,000 .{ }^{71}$ Between 1992 and 1995 , the trustees of the church began to designate the full amount of Richard Warren's compensation as a housing allowance, which he could exclude from his gross income. $^{72}$ In 1996 , they designated $\$ 80,000$ of his $\$ 100,000$ salary as a housing allowance. $^{73}$

The Warrens excluded from their gross income the amounts they spent on "mortgage, utilities, furnishings, landscaping, repairs, and maintenance and real property taxes and homeowner's insurance premiums," which were less than the amount designated as a housing allowance. ${ }^{74}$ It was more, however, than the fair rental value of their home, and the IRS argued that the exclusion should be limited to the lesser of the amount spent on housing or the fair rental value of a minister's home. $^{75}$

The Tax Court disagreed. ${ }^{76}$ On appeal, the Ninth Circuit appointed Professor Erwin Chemerinsky to address whether the court had authority to review the constitutionality of the parsonage allowance, whether it should do so, and whether the allowance was constitutional. ${ }^{77}$

Before the court could review the questions it had asked, though, Congress passed Clergy Housing Allowance Clarification Act of 2002. ${ }^{78}$ Representative Ramstad, who introduced the legislation, explained that his legislation was meant to "stop the attack on the housing allowance by resolving the underlying issue in the tax court

66. Samuel D. Brunson, God and the IRS: Accommodating Religious Practice in UNITED STATES TAX LAW 93 (2018).

67. Taft, supra note 40 , at 1271 .

68. Warren v. Comm'r, 282 F.3d 1119 (9th Cir. 2002).

69. Warren v. Comm'r, 114 T.C. 343,344 (2000).

70. Id.

71. Id.

72. Id. at 345 .

73. Id.

74. Id.

75. Id. at $345-46$.

76. Id. at 351 .

77. Warren v. Comm'r, 282 F.3d 1119, 1119-20 (9th Cir. 2002).

78. Pub. L. No. 107-181, 116 Stat. 583 (2002). 
case."79 After all, he explained, the Ninth Circuit had "hijacked the case and turned it into a challenge of the very constitutionality of the housing allowance" with the aid of "a law professor who happened to believe that it was unconstitutional." 80

Congress's gambit worked. The law provided that, prior to 2002, clergy could exclude housing allowance of up to their full housing expenses. ${ }^{81}$ Going forward, though, the clergy could only exclude up to the fair rental value of their property. ${ }^{82}$ Effectively, it allowed the Warrens to win their litigation, but adopted the IRS's position for future years. ${ }^{83}$ Satisfied, the parties to the litigation filed a motion to dismiss, which the Ninth Circuit granted ${ }^{84}$ At the same time, it denied Professor Chemerinsky's motion to intervene. ${ }^{85}$ This initial constitutional challenge to the parsonage allowance had effectively died.

\section{B. Challenge Number Two: Freedom From Religion Foundation}

About a decade later, the Freedom From Religion Foundation took up Professor Chemerinsky's mantle. The Freedom From Religion Foundation often functions as an Establishment Clause watchdog, "conducting court challenges of violations of the separation between church and state." ${ }^{86}$ On September 13, 2011, The Freedom From Religion Foundation filed a complaint in which it asserted "that 26 U.S.C. $\$ 107$, both on its face and as administered by the Internal Revenue Service ("IRS") and the Department of the Treasury ("Treasury"), violates the Establishment Clause of the First Amendment to the Constitution of the United States by providing preferential tax benefits to ministers of the gospel." ${ }^{87}$ In its complaint, Freedom From Religion Foundation argued that the parsonage allowance violated the Establishment Clause in three respects: first, it was intended to (and did) subsidize religion. ${ }^{88}$ Second, it discriminated against people who were not clergy. ${ }^{89}$ Third, its administration required excessive entanglement between state and church. ${ }^{90}$

While Freedom From Religion Foundation originally challenged the constitutionality of the parsonage allowance's exclusion of both in-kind housing and housing allowances, the district court dismissed the challenge to the exclusion of inkind housing on standing grounds. ${ }^{91}$ But the court held, using a "modified version of

79. 148 CONG. ReC. H1300 (daily ed. Apr. 16, 2002).

80. Id. at $\mathrm{H} 1299$.

81. Erwin Chemerinsky, The Parsonage Exemption Violates the Establishment Clause and Should Be Declared Unconstitutional, 24 WHITTIER L. REv. 707, 708 (2003).

82. Id.

83. Id.

84. Warren v. Comm'r, 302 F.3d 1012, 1013 (9th Cir. 2002).

85. $I d$.

86. Freedom From Religion Found., Getting Acquainted, https://ffrf.org/about/getting -acquainted [https://perma.cc/P49Z-7EPF].

87. Complaint at 1, Freedom from Religion Found., Inc. v. Lew, 983 F. Supp. 2d 1051

(W.D. Wis. 2013), vacated and remanded, 773 F.3d 815 (7th Cir. 2014) (No. 3:11-cv-00626).

88. Id. at 5 .

89. Id.

90. Id.

91. Freedom From Religion Found., Inc. v. Lew, 983 F. Supp. 2d 1051, 1053 (W.D. Wis. 2013), vacated and remanded, 773 F.3d 815 (7th Cir. 2014) ("Because plaintiffs have not 
the Lemon test," 92 that permitting clergy, and only clergy, to exclude cash housing allowances from their gross income violated the Constitution. ${ }^{93}$

On appeal, the Seventh Circuit vacated the district court decision and remanded it to be dismissed for lack of standing. ${ }^{94}$ The court never addressed the merits of the case, instead finding that the plaintiffs in the case lacked standing to challenge the constitutionality of the parsonage allowance because they had never attempted to claim it, and had thus never had their claim denied. ${ }^{95}$ The fact that others receive an allegedly unconstitutional benefit did not, of itself, create a "judicially cognizable injury. "96

In a footnote, though, the Seventh Circuit provided the Freedom From Religion Foundation with a path forward: "to establish standing, a plaintiff must request (and be denied) a benefit, even if, practically speaking, the request has no chance of success." 97 The plaintiffs followed the court's advice, and the Freedom From Religion Foundation designated a portion of the salary it paid to Gaylor and Barker as a housing allowance, which they included in income. ${ }^{98}$ In 2015 , they filed an amended return for 2013 claiming the parsonage allowance. ${ }^{99}$

And the IRS provided them with a refund. ${ }^{100}$ So two months after filing their amended 2013 returns, they filed an amended return for 2012, again claiming the parsonage allowance. ${ }^{101}$ This time, to ensure that the IRS understood that they did not qualify under the terms of the parsonage allowance, they pointed out on their amended return that "they are 'not clergy' and that their 'employer is not a church,'

opposed defendants' argument that plaintiffs lack standing to challenge $\S 107(1)$, I will grant defendants' motion as to that aspect of plaintiffs' claim.").

92. Id. at 1061 .

93. Id. at 1073 .

94. Freedom From Religion Found., Inc. v. Lew, 773 F.3d 815, 825 (7th Cir. 2014).

95. Id.

96. Id. The district court had elided the standing problem, finding "that plaintiffs" alleged injury is clear from the face of the statute and that there is no plausible argument that the individual plaintiffs could qualify for an exemption as 'ministers of the gospel,' so it would serve no legitimate purpose to require plaintiffs to claim the exemption and wait for the inevitable denial of the claim." Freedom From Religion Found., Inc. v. Lew, 983 F. Supp. 2d $1051,1055-56$ (W.D. Wis. 2013). The Seventh Circuit explained that even if requiring the plaintiffs to claim the parsonage allowance and have their claim rejected would not improve the courts' ability to adjudicate the constitutional question, it was nonetheless a constitutional requirement that they take those steps. Freedom From Religion Found., Inc., 773 F.3d at 82425 .

97. Freedom From Religion Found., Inc., 773 F.3d at 824 n.6.

98. Gaylor v. Mnuchin, 278 F. Supp. 3d 1081, 1085 (W.D. Wis. 2017). To be excludable, the housing allowance must be remuneration for "services which are ordinarily the duties of a minister of the gospel." Treas. Reg. $§ 1.107-1$ (a) (as amended in 1963). In addition, the employing church must designate the portion of compensation that represents a housing allowance as such. $I d$. $\S 1.107-1(b)$. While they were not clergy, Gaylor and co-plaintiff Barker were co-presidents of the Freedom From Religion Foundation. Gaylor, 278 F. Supp. 3d at 1085 .

99. Gaylor, 278 F. Supp. 3d at 1085.

100. $I d$.

101. Id. 
but they believed 'it is unfair that ministers can exclude housing while we cannot." "102 This time, the IRS rejected their claim, and they again sued, arguing that the parsonage allowance violated the Establishment Clause. ${ }^{103}$ Again, the district court held the parsonage allowance unconstitutional, ${ }^{104}$ and again the government appealed. $^{105}$

This time, the Seventh Circuit found that the plaintiffs had established an injuryin-fact and had standing to sue. ${ }^{106}$ As such, the court had to address the substance of the complaint, albeit against an Establishment Clause jurisprudence that was "famously chaotic." 107 When questions of religious establishment come up, "the Court cannot even settle on one standard to apply in all Establishment Clause cases." 108

Recognizing that the chaotic mess of Establishment Clause jurisprudence offered little guidance as to what standard to apply, the Seventh Circuit decided to evaluate the constitutionality of the parsonage allowance using two standards: the Lemon test and the "historical significance' test of Town of Greece v. Galloway." 109 The Seventh Circuit decided that, under either test, the parsonage allowance was not inconsistent with the Establishment Clause, and upheld its constitutionality. ${ }^{110}$

The Gaylor court's analysis under the historical significance test failed to engage the complicated history of tax exemptions for churches and parsonages. It looked instead at an imagined history and engaged that imagined history only at a surface level. ${ }^{111}$ To the extent that the historical significance test may become one of the (many) Establishment Clause tests, the Seventh Circuit's opinion provides a poor model for future opinions. Through the rest of this Article, I will proceed to illuminate the complicated and inconsistent history of tax exemptions for churches and parsonages. In doing so, I will describe the analysis in which a court should engage if it wants to employ the historical significance test properly.

102. Id.

103. Id. at 1086

104. Id. at 1104 .

105. Gaylor v. Mnuchin, 919 F.3d 420, 425 (7th Cir. 2019).

106. Id. at 426 .

107. Frederick Mark Gedicks \& Rebecca G. Van Tassell, RFRA Exemptions from the Contraception Mandate: An Unconstitutional Accommodation of Religion, 49 HARV. C.R.C.L. L. REv. 343, 348 (2014).

108. Steven G. Gey, Reconciling the Supreme Court's Four Establishment Clauses, 8 U. PA. J. Const. L. 725, 725 (2006).

109. Gaylor, 919 F.3d at $426-27$.

110. Id. at 435-36 ("Section 107(2), then, does not violated the Establishment Clause under the Lemon test. . . . [W] conclude § 107(2) does not violate the Establishment Clause under the historical significance test.").

111. The court's Lemon test analy sis was also insufficient. While it acknowledged that both the inquiry into the use of a minister's home and the inquiry into who qualified as a "minister of the gospel" for purposes of the parsonage allowance implicated government entanglement with religion, it ultimately chose to defer to Congress rather than establishing a framework for deciding between two potential entanglements. Id. at 434-35. Evaluating such competing entanglements under the Lemon test is beyond the scope of this article, though, and will have to wait for a subsequent article 


\section{The Historical Significance Test}

While the Seventh Circuit appears to have created the name, ${ }^{112}$ the Supreme Court established the historical significance test in Town of Greece v. Galloway. ${ }^{113}$ In Town of Greece, the Supreme Court addressed the question of whether legislative prayer violated the Establishment Clause. ${ }^{114}$ In its analysis, the Court explained that "it is not necessary to define the precise boundary of the Establishment Clause where history shows that the specific practice is permitted. Any test the Court adopts must acknowledge a practice that was accepted by the Framers and has withstood the critical scrutiny of time and political change." 115

Adopting the historical significance test as a potential Establishment Clause test, the Seventh Circuit looked at the long tradition of tax exemptions for religion. It explained that "[f]or over two centuries, the states have implemented church property tax exemptions in various forms." "116 It pointed out that constitutional challenges to these property tax exemptions have been unsuccessful and that the federal government enacted religious property tax exemptions as far back as $1802 .{ }^{117}$ The court found the plaintiffs' objection that property taxes differ substantively from income taxes "too fine a distinction," and ultimately decided that Congress "was continuing its 'historical practice[]' of exempting certain church resources from taxation." 118 Thus, it held, allowing clergy to exclude housing allowances from their gross income was consistent with a long history of constitutionally permissible tax exemptions granted to churches. ${ }^{119}$

While the Seventh Circuit baldly asserted the history of church tax exemptions, its opinion neither laid out that history nor analyzed it. Rather, the opinion cited

112. A Westlaw search for "historical significance test" in All Content brings thirteen hits. The only case that includes "historical significance test" is the Seventh Circuit's opinion in Gaylor. Ten secondary sources include the phrase, and seven of those are discussing the Gaylor case. (One of the other three also deals with a question of religion, while the other two have no Establishment Clause relationship at all.) The search also comes up with two briefs, both of which use it citing the Gaylor case.

113. 572 U.S. 565 (2014).

114. Id. at 569-70 ("The Court must decide whether the town of Greece, New York, imposes an impermissible establishment of religion by opening its monthly board meetings with a prayer.").

115. Id. at 577. After the Seventh Circuit's opinion in Gaylor, the Supreme Court issued an opinion adopting a type of historical significance analysis. Am. Legion v. Am. Humanist Ass'n, 139 S. Ct. 2067, 2083 (2019). That case is not entirely consonant with the Seventh Circuit's version of the test, however. The Seventh Circuit was analyzing the historical significance of a law providing special treatment to religious individuals. The Supreme Court, by contrast, was analyzing the historical significance of "an established monument, symbol, or practice." Id. at 2082. Although the Seventh Circuit dismissed Gaylor's argument that the historical significance test applied only to legislative prayer, Gaylor v. Mnuchin, 919 F.3d 420, $435 \mathrm{n}$.11 (7th Cir. 2019), the Supreme Court's subsequent application of the historical significance test does little to suggest it envisions the test as broad enough to capture tax laws.

116. Gaylor, 919 F.3d at 436 .

117. $I d$.

118. Id.

119. Id. 
Professor John Witte, Jr. in asserting that states have granted religious tax exemptions in various forms over the last two centuries. ${ }^{120}$ However, the court appears not to have read the article it so approvingly cited, because it failed to notice that the article criticized precisely this surface-level narrative of two centuries of consistent and uncontroversial property tax exemptions for religious property. In evaluating the Supreme Court's conclusion in Walz that, among other things, 200 years of states sanctioning religious tax exemptions supported their constitutionality, Professor Witte argued that "[w]hile the Court's conclusion on so tender and tempestuous an issue may have been inevitable, its arguments are not ineluctable."121 In fact, he wrote, "[t]he Court's historical argument depends too heavily upon questionable assertions of fact and selective presentation of evidence." ${ }^{122}$ While there is a long history of tax exemptions for religion, there is an equally long history of criticisms of those exemptions. ${ }^{123}$ Moreover, through much of the country's early history, exemptions were available, not to religion at large, but to established churches, while dissenting religions faced taxation. ${ }^{124}$

Still, the Seventh Circuit adopted the Town of Greece historical significance test as one of its analytical tools. Town of Greece provides that "[a]ny test the Court adopts must acknowledge a practice that was accepted by the Framers and has withstood the critical scrutiny of time and political change." 125 In this Section, I will take that analysis seriously. Rather than imagining 200 years of unbroken tax exemptions for religion, this Section will proceed to look at the history of tax exemptions for religion within the framework that the Supreme Court and the Seventh Circuit adopted as the historical significance test. First, I will look broadly at religious tax exemptions in the country's founding years. Then, I will look the specific history of state tax exemptions for parsonages.

\section{A. A (Brief) History of Religious Property Tax Exemptions}

Today, every state and the District of Columbia exempts at least some religiouslyowned property from its property tax. ${ }^{126}$ Those exemptions do not always trace an unbroken, uncontroversial line back to the founding of the country or the state. ${ }^{127}$ In the following sections, I will attempt to unveil the "questionable assertions of fact and selective presentation of evidence" 128 that have dogged judicial decisions looking at the history of religious tax exemptions. The following subsection will look at religious tax exemptions as they existed during the founding years of the United States. The next subsection will look at how property tax exemptions for religious property developed over the course of the nineteenth century.

120. Id. (citing John Witte, Jr., Tax Exemption of Church Property: Historical Anomaly or Valid Constitutional Practice?, 64 S. CAL. L. ReV. 363, 365-66 (1991)).

121. Witte, supra note 120 , at $365-66$.

122. Id. at 367 .

123. $I d$.

124. $I d$.

125. Town of Greece v. Galloway, 572 U.S. 565, 577 (2014).

126. See infra notes $187-91$ and accompanying text.

127. Witte, supra note 120 , at 367 .

128. Id. 


\section{At the Time of the Framers}

Before looking at the state of religious tax exemptions at the time of the Framers, a caveat: the existence of tax exemptions for religious property in the founding years provides very little information about the Framers' views of the constitutionality of such exemptions. While the meaning of "direct tax" in the Constitution is not completely clear, it certainly includes a tax on real property. ${ }^{129}$ As such, the Constitution would require the federal government to apportion the property tax to the states according to their populations. ${ }^{130}$ This apportionment would lead to citizens paying different rates of tax on their property depending on the population of the state they lived in. ${ }^{131}$ An apportioned property tax could "create great inequality and injustice," 132 and thus, federal direct taxes were rare. ${ }^{133}$ States face no such limitation. ${ }^{134}$ Because the federal government could not realistically tax real property, questions of the tax treatment of religious property necessarily find their answers at the state level.

It is also important to keep in mind that during the first 150 years of the United States, the religion clauses did not apply to limit state governments' actions. The Establishment Clause was not incorporated against the states until 1947. ${ }^{135}$ Early state constitutions generally adopted whatever religious protections the state had offered prior to independence. ${ }^{136}$ As a result, state treatment of religious property does little to elucidate the constitutional limitations of tax benefits to religion. ${ }^{137}$ Nonetheless, in this Article's bid to explore the historical significance of tax-free parsonages, I will look at how the early states treated religious property for tax purposes.

129. Dawn Johnsen \& Walter Dellinger, The Constitutionality of a National Wealth Tax, 93 IND. L.J. 111, 121 (2018) ("Finally, real property or land taxes constitute the third "other direct' tax that the evidence suggests the Framers may have had in mind."); see also Erik M. Jensen, Did the Sixteenth Amendment Ever Matter? Does It Matter Today?, 108 Nw. U. L. REV. 799, 808 (2014) ("And we can be certain that a tax on real property is direct.").

130. U.S. CONST. art. I, $\S 2$, cl. 3. For a more thorough discussion of federal direct taxes, see infra notes 371-81.

131. Cf. Samuel D. Brunson, Paying for Gun Violence, 104 MinN. L. Rev. 605, 628-29 (2019).

132. Hylton v. United States, 3 U.S. 171, 174 (1796).

133. See infra notes $375-76$ and accompanying text.

134. Evgeny Magidenko, Classifying Federal Taxes for Constitutional Purposes, 45 U. BALT. L. REV. 57, 126 (2015) ("Unlike the federal government, the states do not have any federal constitutional restrictions on their ability to levy direct taxes.").

135. "The broad meaning given the Amendment by these earlier cases has been accepted by this Court in its decisions concerning an individual's religious freedom rendered since the Fourteenth Amendment was interpreted to make the prohibitions of the First applicable to state action abridging religious freedom. There is every reason to give the same application and broad interpretation to the 'establishment of religion' clause." Everson v. Bd. of Ed. of Ewing Twp., 330 U.S. 1, 15 (1947); see also Frederick Mark Gedicks, Incorporation of the Establishment Clause Against the States: A Logical, Textual, and Historical Account, 88 IND. L.J. 669, 670 (2013).

136. Witte, supra note 120 , at 380.

137. For a discussion of state constitutions' treatment of religion, see infra Section III.A.2. 
In many cases, the early states exempted church property from taxation. The reason for such continued exemptions is unclear: they "simply continued, even as churches were disestablished, with little apparent discussion." 138 The importance of the existing exemptions is also debatable in many cases. Unlike today, in the early Republic, states were inconsistent in imposing and collecting taxes. As of 1796, for instance, New York had not levied a general or direct tax in eight years. ${ }^{139}$ In fact, New York's laws did not even define objects of taxation. ${ }^{140}$ Instead, "the Legislature determines the quotas to be paid by counties, [and] the supervisors of counties determine the quotas of towns, which last are apportioned to individuals by assessors." 141 While Pennsylvania had a defined set of tax laws, it, too, went a full decade without imposing a general tax. ${ }^{142}$

Many of the states continued their colonial tax exemptions for churches and for ministers of the gospel after Independence. At the time, individuals' income was largely irrelevant, except in Delaware, which solely imposed an income tax. ${ }^{143}$ The other states imposed poll and property taxes as part of their panoply of taxes. ${ }^{144} \mathrm{~A}$ number of states exempted ministers of the gospel from their poll taxes, while more exempted church property from the property tax. In neither event, though, was the benefit of exemption allowed solely to religion.

For example, Pennsylvania exempted ministers from its poll tax. ${ }^{145}$ It also exempted schoolmasters, mechanics, and manufacturers. ${ }^{146}$ Connecticut exempted "settled ministers of the Christian religion" and the president of Yale college. ${ }^{147}$ Rhode Island also exempted settled ministers of the Christian religion from poll taxes. ${ }^{148}$ In Massachusetts, settled ministers were joined by the "president, fellows, professors, tutors, librarian, and students of Harvard college," as well as grammarschool masters and the masters of other academies. ${ }^{149}$ Vermont similarly exempted "settled ministers of the Christian religion, the president and tutors of colleges, constant schoolmasters, students of colleges, until three years after receiving their first academical degrees; as, also, in favor of persons disabled by sickness or infirmity." 150

And how did the states treat religious property under their property tax regimes? Those that granted exemptions for religious property did so in one of three manners:

138. Stephen Diamond, Efficiency and Benevolence: PhILANThropic Tax EXeMPtions IN 19th-Century AMERICA in Property-Tax EXEMPTION For Charities 115, 118 (Evelyn Brody ed., 2002).

139. See H.R. Doc. No. 4-100, at 425 (1796).

140. Id.

141. Id.

142. Id. at 427 .

143. Id. at 429 .

144. A "poll tax" is a tax under which "[e]veryone is assessed a tax bill that does not depend on how much they earn or any other economic activity." LEONARD E. BURMAN \& JOEL Slemrod, TAXes in AMERICA: What Everyone NeEdS to KnOw 128 (2012).

145. H.R. Doc. No. 4-100, at 427 (1796).

146. Id.

147. Id. at 424 .

148. Id. at 423 .

149. Id. at 420 .

150. Id. at 418 
they exempted ministers broadly from poll and property taxes, they exempted property based on its ownership, or they exempted property based on its use. Connecticut and Massachusetts provide examples of the first manner: they exempted ministers from their poll taxes and also exempted the ministers' property from property tax. ${ }^{151}$ Vermont also exempted ministers' property, but only to the extent its value did not exceed 500 pounds. ${ }^{152}$ (States that exempted property owned by ministers from property tax also exempted the property of other classes of people who were exempt from the poll tax.)

The second manner of exemption was for property belonging to religious organizations. South Carolina was the only state fitting into this category, with an exemption for "[p]roperty belonging to religious or charitable societies, cities, or free schools." ${ }^{153}$ Delaware theoretically also fit into this category, but its income tax was not working well. In 1796, it had enacted, though not yet implemented, a property tax which would exempt, among other things, "property belonging to ... any ... religious society." 154

The final manner of exemption looked at the use of the property. In addition to exempting the property of ministers, Connecticut exempted "all lands or buildings sequestered for schools, or other public or pious uses." 155 Maryland exempted "houses for public worship," 156 while Virginia and Rhode Island were more explicit about their use requirement, with both states exempting "houses dedicated to public worship." 157

This ad hoc collection of approaches to religious exemptions is hardly surprising. In these early years there was not yet a "universal system of taxation, no general property tax that attempted to identify all property within the jurisdiction and tax it at the same ad valorem rate." ${ }^{158}$ Exemptions existed more as a way to demonstrate government favoritism than as an instrument of financial benefit. ${ }^{159}$ Exemptions were largely carried over from colonial days, before the passage of the Constitution and the Bill of Rights. It would be a century and a half until the Establishment Clause even applied to the states. While the early tax laws of several states did exempt religious property from taxation, baldly pointing to them as evidence that religious property tax exemptions have been acceptable since the Founding era "ignores the variety of theories that supported these laws." 160

Looking at the state-level property tax exemptions around the time of the Founding does little more to help determine the historical significance of an exemption for parsonages. Its lack of relevance comes in part because the

151. Id. at 420,424 .

152. Id. at 418 .

153. Id. at 435 .

154. Id. at 429 .

155. Id. at 424 .

156. Id. at 429 .

157. Id. at $423,431$.

158. DiAMOND, supra note 138, at 118-19.

159. Id. at 119 .

160. Witte, supra note 120 , at 367 . Those theories ranged from support for exemption deriving from "the almost innate promptings of the human heart" to the lack of income from property. Diamond, supra note 138, at 121-22. 
Establishment Clause was irrelevant to the question of what states could do. It is also unhelpful because the exemptions that existed for religious property never explicitly mentioned parsonages. Certain minister-owned property was exempt, and certain property used as a house of worship was exempt, but only one state exempted property by virtue of being owned by a church. To understand the place of parsonages in state tax regimes, then, will require us to look at tax developments over the subsequent two centuries.

\section{Religious Property Taxes after the Founding}

While the early states largely kept their colonial property tax exemptions intact, the exemptions were largely ad hoc, and largely limited to organizations that had received exemption as part of their initial charter. By the late nineteenth century, the foundations of those exemptions had grown shaky. ${ }^{161}$ Disestablishment, the states' move away from English equity law, and the emerging preference for universal, not selective, taxation meant that states would have to come up with a new theory of exemption if they were to continue to exempt religious property from taxation. ${ }^{162}$

The country began to come to a general consensus about exempting religious property from its general property taxes: states should exempt church property from taxation because churches benefited both society in general and the state in particular. ${ }^{163}$ If that were the case-and there was broad agreement that it was-the exemption benefitted, not religion, but the state itself. ${ }^{164}$ In fact, proponents of exemption argued that taxing church property would "be unjust and injurious both to the churches and to the State." 165

Still, this emerging consensus faced growing pains. In particular, it is worth looking at California and at the District of Columbia to illustrate that the line between carryover colonial exemptions and the modern religious property tax exemption is not a clean line.

The District of Columbia provides an instructive look at how the federal government viewed property tax exemptions for religious property. While the Establishment Clause did not apply to the states until its incorporation in $1947,{ }^{166}$ the Bill of Rights directly constrains the District of Columbia, "without need for the intermediary of incorporation." 167

In 1874, Congress enacted a property tax in the District of Columbia, taxing property in Washington at a rate of three percent of assessed value, in Georgetown

161. Witte, supra note 120 , at $380-81$.

162. Id. at 381-86.

163. Id. at $386-87$.

164. Id. at 387. Still, some continued to oppose the exemption of religious property from the property tax. Many critics "focused on Catholic opulence ... and contrasted it to a Protestant esthetic of simplicity." Diamond, supra note 138, at 126. Others even included "ostentatious Protestant churches in the condemnation." Id.

165. Henry W. Foote, The Taxation of Churches, 7 Unitarian Rev. \& Religious MAGAZINE 349, 351 (1877).

166. See supra note 135 and accompanying text.

167. Parkerv. D.C., 478 F.3d 370, 391 n.13 (D.C. Cir. 2007), aff'd sub nom. D.C. v. Heller, 554 U.S. 570 (2008). 
of 2.5 percent, and outside of those two cities, at two percent. ${ }^{168}$ The law exempted property owned by the federal government, the District of Columbia, and by charitable and educational institutions. ${ }^{169}$ The tax commissioners in the District understood that this exemption did not include churches, and began to levy taxes on religious property. ${ }^{170}$ The District continued to tax churches for five years, until Congress passed a new law repealing the property tax as it applied to "church property which was actually held and used for the purpose of divine worship."171 Congress not only exempted churches in the District of Columbia from the property tax-it also returned to the religious trustees the title of church property that had been sold for nonpayment of taxes and required the District to refund property taxes that had been paid by churches. ${ }^{172}$ Ultimately the District of Columbia's experiment with taxing church property had no substantive lasting impact. Nonetheless, for five years in the late nineteenth century, the federal government imposed a property tax on all religiously owned property, including parsonages. ${ }^{173}$

California, too, taxed religiously owned property for more than thirty years. Acquired by the United States in $1848,{ }^{174}$ the territory of California became a state two years later. ${ }^{175}$ Between its acquisition by the United States and its attaining statehood, California drafted and ratified a constitution. ${ }^{176}$ That original constitution illustrated the move to universal taxation, providing that "[ $t$ ]axation shall be equal and uniform throughout the State. All property in this State shall be taxed in proportion to its value ...."177

In spite of the state constitution's plain language, the California legislature originally provided for pre-statehood exemptions to continue. ${ }^{178}$ Thus, by 1859 , California law exempted land owned by:

[C]olleges, school houses and other buildings for the purpose of education, public hospitals, asylums, poor houses and other charitable institutions for the relief of the indigent and afflicted, churches, chapels and other buildings for religious worship, together with lots of ground and other property appurtenant thereto; cemeteries and graveyards; the

168. An Act for the Government of the District of Columbia, and for Other Purposes, ch. 337,18 Stat. $117 \S 4$ (1874).

169. Id.

170. See Diamond, supra note 138 , at 125.

171. An Act to Relieve the Churches of the District of Columbia, and to Clear the Title of the Trustees of Such Property, ch. 33, 21 Stat. 23 (1879).

172. Id.

173. Moreover, it is not clear that the 1879 law would have exempted parsonages. Its language was limited to property used for "the purpose of divine worship." Id. That use requirement has gone different ways in different jurisdictions.

174. Gary Lawson \& Guy Scidman, The Hobbesian Constitution: Governing Without Authority, 95 Nw. U. L. REv. 581, 582 (2001).

175. Id.

176. Id. at 586 .

177. CAL. ConSt. OF 1849, art. XI, $\S 13$.

178. Diamond, supra note 138, at 120. 
property of widows and orphan children to the amount of one thousand dollars; growing crops and mining claims. ${ }^{179}$

The state supreme court stripped virtually all of these property tax exemptions away in $1868 .{ }^{180}$ The court explained that if the legislature had the power to exempt crops and mining claims, "the exemption may be carried still further, until property of one class is made to bear the whole burden of taxation." 181 Any exemption that included private property, the court held, was "in plain violation of the command of the Constitution." 182

In 1900, California amended its constitution to allow for the exemption of religious property. ${ }^{183}$ But for the more than three decades between the McCreery decision and the amendment of the state constitution, California's property tax exemplified the policy of universal taxation, and religious organizations paid property tax on their property. Because the state's gap in exemption resulted from a policy of universal taxation in its state constitution, it does not speak to the constitutionality of exempting parsonages from the property tax. It does, however, undercut the clean narrative of two centuries of unbroken tax exemption for religious property. The Establishment Clause did not prohibit states or the federal government from taxing religiously owned property. ${ }^{184}$

\section{PROPERTy TAXES AND PARSONAGES}

Even after religious property tax exemptions became universal, the question of the treatment of parsonages did not. While most states expressly exempt houses of worship from their property tax, in many states other property belonging to religious organizations qualifies for exemption only if its use qualifies as religious or otherwise charitable. ${ }^{185}$ When it comes to parsonages, states have answered the question of whether the property tax exemption applies inconsistently, both across states and across time. In this part, I will first categorize states according to whether and how they currently exempt parsonages from their property tax. Next, to determine whether the exemptions have "withstood the critical scrutiny of time and political change," 186 I will look at those states that have changed their property tax treatment of parsonages.

179. People v. McCreery, 34 Cal. 432,457 (1868).

180. Diamond, supra note 138, at 120.

181. McCreery, 34 Cal. at 457.

182. Id.

183. Diamond, supra note 138 , at 120.

184. Even today, mere religious ownership does not guarantee property tax exemptions. In Illinois, for example, an exempt church that leases space in its building to a preschool must pay property tax on that portion of the property used by the preschool. First Presbyterian Church of Libertyville v. Ill. Dept. of Revenue, No. 09 PT 0066 (2010), https://www2.illinois.gov/rev/research/legalinformation/hearings/pt/Documents/pt10-10.pdf [https://perma.cc/968W-H838].

185. See, e.g., Janne Gallagher, The Legal Structure of Property-Tax Exemption, in PROPERTy-TAX EXEMPTION FOR ChaRITIES: MAPPING THE BATtLeFIEld 3, 5 (Evelyn Brody ed., 2002).

186. Town of Greece v. Galloway, 134 S. Ct. 1811, 1819 (2014). 


\section{A. Current Property Tax Treatment of Parsonages}

Today, twenty-nine states and the District of Columbia statutorily exempt parsonages from property tax. ${ }^{187}$ The other twenty-one states provide constitutional or statutory property tax exemptions for at least some religious property, but do not specifically exempt parsonages. In eight of these states, courts (or, in one case, regulations) include parsonages in the set of exempt religiously owned property. ${ }^{188}$ In three states, courts allow the exemption of some parsonages, depending on the use of those parsonages. ${ }^{189}$ In three states, the general religious property tax exemption does not exempt parsonages from paying property taxes. ${ }^{190}$ In the remaining four states, courts have not ruled on the question of whether parsonages qualify as exempt religious property. ${ }^{191}$

\section{Explicit Exemptions}

Even among the states that explicitly exempt parsonages by statute, the exemption is not always absolute. All impose certain limits and requirements on the property tax exemption. For example, every state that explicitly exempts parsonages requires that the parsonage be owned by the religious organization, not by individual clergy. ${ }^{192}$

There are also other requirements that differ among the various jurisdictions. In Washington, D.C., any given church or congregation can own only one parsonage

187. See infra Appendix 1 for a list of the states that explicitly exempt parsonages from the property tax. It is important to note that, while I include Hawaii among the twenty-nine states that explicitly exempt parsonages, it is in a slightly odd position: in 2016, the state eliminated its state real property tax. 2016 Haw. Sess. Laws $85,86 \S 6$. Years earlier, the Hawaii Supreme Court held that the state's constitution had shifted the authority to tax real property from the state to the counties. State ex rel. Anzai v. City \& Cnty. of Honolulu, 57 P.3d 433, 435 (Haw. 2002). Prior to the 2016 repeal, state law exempted "[p]roperty used for church purposes, including . . parsonages." HI REv. STAT. § 246-32(b)(3) (2012). While the Hawaii legislature repealed that provision in 2016, four of the five counties in Hawaii have enacted a property tax exemption with identical language. MaUt, HaW., CODE OF OrdinanCES $\$ 3.48 .495$ (b)(3); Haw., Cnty. Code 1983 § 19-77(b)(3) (2016 Edition, as amended); Honolulu, Haw., Rev. Ordinance 8-10.10(b)(3); KaUA'I, Haw., 3 CNTY. CODE Tit. III, § 5A-11.10(b)(3).

188. See infra Appendix 2.

189. See infra Appendix 3.

190. See infra Appendix 4.

191. See infra Appendix 5.

192. See, e.g., AlaSKa StaT. ANN. $\S 29.45 .030$ (b) (West) (exempting parsonages as long as they are owned by a religious organization); N.Y. REAL PROP. TAX LAW $\$ 462$ (McKinney) (exempting "property owned by a religious corporation while actually used by the officiating clergymen thereof for residential purposes"). New York provides a partial exception to this broader rule. The New York property tax law provides a special exemption for "[r]eal property owned by a minister of the gospel, priest or rabbi of any denomination." N.Y. REAL PROP. TAX LAW $\S 460$ (McKinney). For any such clergy residing in the state, up to $\$ 1500$ of real property is exempt from the state property tax. $I d$. This exemption is not precisely an exemption of a parsonage, though: it is not limited to residential real property, nor to property used or occupied by clergy. 
that is exempt from property taxation. ${ }^{193}$ New Jersey exempts up to two parsonages owned by "any religious corporation of this State."194

New Jersey also exempts the land parsonages sit on, as long as that land does not exceed five acres. ${ }^{195}$ North Dakota limits the size of exempt parsonages to two acres if the parsonage is not located on the same parcel of land as the buildings used for religious purposes. ${ }^{196}$ Rhode Island limits the exempt amount of land on which a parsonage sits to the greater of one acre or the minimum lot size permitted where the parsonage is located. ${ }^{197}$

Texas imposes a size limitation similar to Rhode Island's: Texas exempts real property owned by a religious organization that "is reasonably necessary for use as a residence," but in no event larger than one acre. ${ }^{198}$ In addition, to qualify for the exemption, the parsonage must be used "exclusively as a residence" for clergy and cannot produce any revenue for the religious organization that owns it. ${ }^{199}$ In Indiana, while parsonages are exempt from property tax, the religious organization that owns it must provide an affidavit to the assessor stating that the parsonage houses clergy and that the religious organization does not make a profit from the parsonage. ${ }^{200}$

Maine goes another direction with its limitations. Instead of limiting the size of exempt parsonages, it limits the exempt value. A parsonage in Maine is exempt from property taxation on its first $\$ 20,000$ of value. ${ }^{201}$ Illinois goes yet another direction. Property owned by religious organizations and used as housing for clergy is exempt, provided that the clergy must, "as a condition of their employment or association, reside in the facility." 202

These twenty-nine states and the District of Columbia have made the explicit legislative decision to exempt parsonages from the property tax. It is important to keep in mind, though, that none of these states provides an unconstrained exemption for any housing designated as a parsonage. Rather, they all require that the parsonage be owned by an exempt religious organization. Many also impose additional limitations, including limitations on the size, location, or value of the parsonage. In all of these states, there is an implicit recognition that exempting parsonages is an exception from the general rule of property tax, one that must be made explicit in the statute.

193. D.C. Code ANN. $\$ 47-1002$ (West).

194. N.J. StAT. ANN. $\S 54: 4-3.6$ (West).

195. Id.

196. N.D. Cent. Code AnN. \& 57-02-08(9)(a) (West). If the parsonage is located on the same parcel of land, North Dakota does not impose any acreage limitations. Id.

197. 44 R.I. GEN. Laws ANN. \& 44-3-3 (West).

198. TeX. TAX CODE ANN. $\& 11.20$ (a)(3) (West).

199. Id.

200. IND. CODE $\S 6-1.1-10-21(\mathrm{c})$.

201. Me. Rev. Stat. tit. $36, \S 652(1)(\mathrm{G})$.

202. 35 Ill. COMP. StAT. 200/15-40(b). That requirement mirrors the federal income tax's general exclusion for employer-provided housing, available only if, among other requirements, "the employee is required to accept such lodging on the business premises of his employer as a condition of his employment." I.R.C. $\$ 119(\mathrm{a})(2)$. 


\section{Non-Statutory Exemptions for Parsonages}

The remaining twenty-one states do not constitutionally or statutorily exempt parsonages from their property taxes. They do, however, exempt at least some religiously owned or used property. Many use a similar formulation to determine whether the property tax reaches religious property: they exempt property that is both owned by a religious organization and is used exclusively for religious purposes. ${ }^{203}$ The question then becomes whether housing clergy is a religious purpose under the property tax exemption.

Eight states have concluded that it is. For seven states in this category, the courts have exempted parsonages. For instance, in Delaware there is a statutory exemption for property "owned by . . . any church or religious society, and not held by way of investment." ${ }^{204}$ When the city of Wilmington assessed a city and school tax against a rectory building owned by Roman Catholic Diocese of Wilmington, the diocese challenged the validity of the assessment. ${ }^{205}$ The diocese argued that a rectory fell within the state's exemption from property tax, while the city argued the opposite. ${ }^{206}$ The court ultimately found that it fit within the statutory exemption for religious property because the rectory belonged to a religious organization, and because it was not held for investment. ${ }^{207}$

The Nebraska statutory exemption for religious property applies to a narrower slice of property. As with Delaware, in Nebraska a religious organization must both own the land and not use it for financial gain. ${ }^{208}$ In addition, for religiously owned property to qualify for the exemption, a religious organization must use the land "exclusively for ... religious ... purposes."209

Nebraska courts had to wrestle with the question of whether housing clergy qualified as a religious purpose. Surprisingly, they did not wrestle with the question until the 1990 s. ${ }^{210}$ The court emphasized that "exclusively" meant "primarily," and

203. See, e.g., Mo. Const. art. X, $\S 6(1)$; see also Iowa CodE ANN. $\S 427.1(8)$ (a) (West) (exempting property "owned by a religious institution ... if all monetary and in-kind profits of the religious institution or society resulting from use or lease of the grounds are used exclusively by the religious institution or society for the appropriate objects of the institution or society").

204. Del. Code AnN. tit. $9, \S 8105$ (West).

205. St. Stanislaus Kostka Church v. Mayor of Wilmington, 105 A.2d 596, 597 (Del. Super. Ct. 1954).

206. Id. at 598 .

207. Id. at 599 .

208. Neb. Rev. Stat. Ann. \& 77-202(1)(d) (West). Nebraska law imposes two other rules that are not relevant here. Exempt land cannot be used to sell alcoholic liquors for more than twenty hours per week and cannot be owned by organizations that discriminate based on an individual's race, color, or national origin. $I d$.

209. Id.

210. Nebraska Ann. Conf. of United Methodist Church v. Scotts Bluff Cnty. Bd. of Equalization, 499 N.W.2d. 543, 547 (Neb. 1993) ("This is the first opportunity for this court to address the question of whether a cleric's use of a parsonage constitutes exclusive religious use for exemption purposes."). Perhaps the question had never come to the courts previously because the taxing authorities in Nebraska had previously assumed that parsonages qualified as tax-exempt, notwithstanding the ambiguity in the law. $I d$. at 545 ("The parsonage has 
that incidental non-religious use would not cost a property its tax exemption. ${ }^{211}$ Still, to qualify as tax exempt, housing clergy has to qualify as a religious purpose. The court determined that it does, as long as the housed member of clergy engages in ministerial work full time, the employer-church provides the housing for the church's and its members' convenience, and the parsonage "serves numerous religious purposes."212

Oklahoma courts had to make a similar determination. Like Nebraska, the Oklahoma constitution exempts "all property used exclusively for religious and charitable purposes." ${ }^{213}$ While the Oklahoma constitution does not appear to impose an ownership requirement, it imposes a similar exclusive use requirement. The court explained that this exclusive use requirement had three parts: the parsonage had to be owned by a church and to house a pastor engaged in full-time ministerial work, the church had to provide the parsonage as part of the pastor's compensation, and the parsonage had to "serve[] various religious purposes." 14 As long as it met these criteria, the court said, it met the exclusive use requirement and qualified for tax exemption. ${ }^{215}$

While the Oklahoma court came to the same conclusion as the Nebraska court, the conclusion was neither inevitable nor uncontroversial. In fact, one judge dissented from the court's conclusion. Justice Hodges pointed out that the parsonage was a "private dwelling residence," not unlike any other non-exempt private residence. ${ }^{216}$ In general, the dissent explained, exemptions from property tax are strictly construed. ${ }^{217}$ Because the use of a parsonage was personal rather than religious, and because the state constitution did not expressly list parsonages as exempt, the dissent argued that any ambiguity in the constitution should be read against granting the exemption.

In looking at non-statutory exemptions for parsonages, New Mexico, the eighth state in this category, is something of an outlier. Under New Mexico's constitution, "all church property not used for commercial purposes . . . shall be exempt from taxation." 218 While a parsonage could certainly fit into the category of church property not used for commercial purposes, the property tax statute is unhelpful in determining whether the constitutional exemption includes parsonages. It merely provides that all property is subject to property tax valuation unless explicitly exempted. ${ }^{219}$ And, in relevant part, it explicitly exempted "property exempt from property taxation under the federal or state constitution, federal law, the Property Tax Code or other laws." ${ }^{220}$ Rather than relying on the courts to determine whether

continuously applied for, and received, tax-exempt status in the past, and on December 27, 1989, application was made by United Methodist for continued tax exemption.").

211. Id. at 547 .

212. Id. at 548 .

213. OKLa. Const. art. X, $\S 6$.

214. Immanuel Baptist Church v. Glass, 497 P.2d 757, 760 (Okla. 1972).

215. Id.

216. Id. (Hodges, J., dissenting).

217. Id. at 761 (Hodges, J., dissenting).

218. N.M. CONST. art. VIII, $\S 3$.

219. N.M. STAT. ANN. $\S 7-36-7$ (A) (West).

220. Id. $\S 7-36-7(\mathrm{~B})(1)$. 
qualifies as church property not used for commercial purposes, New Mexico enacted regulations providing that the state constitution's exemption includes both buildings used for religious purposes and buildings used "for residences of the priests, ministers, chaplains, pastors or rabbis." 221

As with the states that explicitly exempt parsonages from the property tax, parsonages end up being exempt in these states. They are not exempt, though, as a result of legislative decision. Instead, they are exempt because courts have determined that housing clergy meets the broad exemption requirements for religiously owned property broadly. By and large, courts in these states have determined that providing housing for clergy serves primarily religious purposes, and that the personal benefits to clergy are, at most, incidental.

\section{Parsonage Exemption Depends on Use}

As with the prior category, California, Oregon, and Tennessee provide for a general property tax exemption for religious property, but none of the three states expressly exempts parsonages. Unlike the eight states in the prior category, though, courts have held that parsonages qualify for the exemption, but only under certain circumstances.

The California property tax exemption for religious property is similar in many ways to Nebraska's. It too applies to property used "exclusively for religious ... purposes" and owned by religious entities. ${ }^{222}$ The law goes on to specify that the owner cannot be organized for profit, that the net earnings of the owner cannot inure to the benefit of any individual or shareholder, and that the owner use the property "for the actual operation of the exempt activity." 223 For parsonages, this raises similar questions as those answered by the Nebraska court: is housing clergy an exclusively religious purpose, and is it the actual operation of the exempt activity?

In answering these questions, the California Court of Appeals explained that whether a parsonage qualified for exemption had to be determined on a case-by-case basis. ${ }^{224}$ The owner of the parsonage had the burden of demonstrating that it used the parsonage "for some type of institutional necessity" and that this institutional necessity was something more than merely providing a residence for clergy. ${ }^{225}$

Oregon provides an even narrower religious exemption from property tax than California. "[H]ouses of public worship" owned by religious institutions qualify for the exemption. ${ }^{226}$ Other property owned by religious institutions qualifies, too, provided that property is used by the religious organization "solely for administration, education, literary, benevolent, charitable, entertainment[,] and recreational purposes." 227

221. N.M. Admin. CODE 3.6.5.15(L)(2) (as amended in 2001).

222. CAL. REV. \& TAX. CODE $\S 214$ (a).

223. Id.

224. First United Methodist Church v. L.A. Cnty., 208 Cal. Rptr. 85, 91 (Cal. Ct. App.

1984).

225. $I d$.

226. Or. Rev. Stat. AnN. $\S 307.140(1)$ (West).

227. Id. 
In determining whether religious property is exempt from property tax, Oregon courts apply a two-prong inquiry. The first prong asks whether the religious use of the property is "primarily for the benefit of the church." 228 The second prong asks whether the religious use of the property is "reasonably necessary for the furthering of the religious aims of the church." 229

The court's analysis under the first prong recognizes the distinction between primary and incidental benefits. As long as the religious organization gets the primary benefit of the use of the property, incidental benefits to individuals will not disqualify it. ${ }^{230}$ By contrast, where the primary benefit lies elsewhere, and the religious organization only receives an incidental benefit, the property will fail the first prong.

The second prong applies differently to residential property than it does to nonresidential property. ${ }^{231}$ For residential property such as a parsonage to qualify as exempt, the religious organization must require the clergy member to live there (either as a matter of religious doctrine or out of practical necessity) and "the proximity of the residence to the house of worship must be necessary to further religious objectives." 232

So, for instance, where the "continuous presence" of clergy is needed "to attend to the religious needs of the congregation," and the parsonage is "substantially used for church functions or rites, entertaining or counseling members of the church and the like," a parsonage can qualify as tax-exempt under Oregon law. ${ }^{233}$ Oregon courts are perfectly willing to hold that religious organizations must pay property tax on parsonages that do not meet the two criteria. ${ }^{234}$

Finally, Tennessee also exempts property owned by religious institutions provided that the religious institution uses the property for "carrying out one (1) or more of the exempt purposes for which the institution was created or exists." 235 As with Oregon and Nebraska, the statutory exemption does not explicitly include parsonages. The Tennessee Court of Appeals explained that, while parsonages may qualify as exempt, they "per se, are not given exemption under the statute; only those pieces of property that are used purely and exclusively for religious, charitable, scientific or educational purposes are exempt."236 In Tennessee, the court held that merely housing clergy - even where the clergy uses the parsonage as a home base

228. Washington Cnty. Assessor v. W. Beaverton Congregation of Jehovah's Witnesses, Inc., 18 Or. Tax 409, 418 (2006).

229. Id.

230. Id.

231. Id.

232. Id. at 419. These standards are nearly identical to the requirements of the for-theconvenience-of-the-employer exclusion for employer-provided housing. See I.R.C. § 119.

233. German Apostolic Christian Church v. Dep't of Revenue, 569 P.2d 596, 599-600 (Or. 1977).

234. See, e.g., Washington Cnty. v. Dep't of Revenue, 11 Or. Tax 251, 254-55 (1989) (holding that a parsonage, used primarily for housing, did not qualify for a property tax exemption).

235. Tenn. Code AnN. § 67-5-212(a)(1) (West 2018).

236. Blackwood Bros. Evangelistic Ass'n v. State Bd. of Equalization, 614 S.W.2d 364, 366 (Tenn. Ct. App. 1980). 
for their evangelizing - does not make its use exclusively religious ${ }^{237}$ The Tennessee court also held that even using a parsonage purely and exclusively for religious purposes does not automatically grant it a property tax exemption; any given church can only own one property tax-exempt parsonage. ${ }^{238}$

These three states are similar to the seven states that judicially exempted all parsonages. They, too, had to grapple with the question of whether providing housing for clergy constituted the carrying out of a religious purpose. Unlike the previous seven, though, their courts determined that housing clergy only sometimes primarily benefited the religious organization. Parsonages used solely for housing clergy did not qualify. As such, the question of exempting parsonages from the property tax in these states is a question of fact, and each parsonage must be considered individually.

\section{Parsonages Are Not Exempt}

Like the states discussed in the previous two subsections, Ohio, Pennsylvania, and Utah have a general property tax exemption for some property owned by religious institutions. In these three states, however, the exemption does not extend to parsonages. The reasoning differs in each state, but the result is the same: religious organizations that own parsonages in these three states must pay property tax on those parsonages.

Ohio law exempts "[h]ouses used exclusively for public worship, the books and furniture in them, and the ground attached to them" from the property tax, as long as the houses are not leased or otherwise used for profit. ${ }^{239}$ It also exempts real property "owned and operated by a church that is used primarily for church retreats or church camping, and that is not used as a permanent residence." 240

By definition, a parsonage is used as a permanent residence by clergy and is therefore excluded from the exemption. In 1989, the Ohio Supreme Court upheld a decision by the state's Board of Tax Appeals holding that a parsonage did not qualify as exempt from property taxation. ${ }^{241}$ More recently, in dicta, the supreme court characterized the idea that residential property does not qualify for tax exemption as "well-settled," 242 though only the dissent referred explicitly to the statutory exclusion of permanent residences. ${ }^{243}$

Unlike Ohio, Pennsylvania does not explicitly exclude parsonages from its property tax exemption. Rather, it provides a general religious exemption for "[a]ll churches, meeting-houses, or other actual places of regularly stated religious worship." 244 According to the courts, regularly stated religious worship means that the "primary application" of the property must be for regularly scheduled and

237. Id.

238. Id.

239. Ohio Rev. Code AnN. § 5709.07(A)(2) (LexisNexis 2019).

240. Id. $\S 5709.07(\mathrm{~A})(3)$.

241. Full Gospel Apostolic Church v. Limbach, 546 N.E.2d 403 (Ohio 1989).

242. Grace Cathedral, Inc. v. Testa, 36 N.E.3d 136, 141 (Ohio 2015).

243. Id. at 150 ( $\mathrm{O}^{\prime}$ Connor, C.J., dissenting). According to the dissent, the majority may not have mentioned the statutory exclusion because the taxpayer did not refer to it in claiming its property tax exemption. Id.

244. 72 Pa. Stat. ANd Cons. Stat. Ann. § 5020-204(a)(1) (West 2013). 
consistent "conduct of worship." 245 Meanwhile, the actual place requirement does not require that the property be used solely for worship. Rather, its "primary purpose" must be worship, but a qualifying property does not lose its exemption if it has other incidental uses. ${ }^{246}$

Under this analysis, parsonages do not qualify as actual places of regularly stated religious worship. In dealing with whether a building that was formerly used as a parsonage was exempt from tax, the Commonwealth Court of Pennsylvania acknowledged, offhandedly and without analysis, that "[t]he home was used as a parsonage until August 23, 2001, during which time it was taxable." ${ }^{247}$ Given the relatively specific requirements under Pennsylvania statutory and common law, a parsonage used principally for housing clergy is subject to state property tax.

Finally, the Utah Constitution exempts "property owned by a nonprofit entity used exclusively for religious, charitable, or educational purposes." ${ }^{248}$ As with other states that have an exemption that excludes property used "exclusively" for religious purposes, Utah courts had to determine whether housing clergy qualified as an exclusive religious purpose. In 1976, the question of whether parsonages qualified for exemption reached the Utah Supreme Court for the first time. ${ }^{249}$ The court looked to other states without an express exemption, and determined that, while decisions went both ways, "the decided weight of authority supports the rule that parsonages, residences of ministers, and parish houses owned by a church and occupied as a residence by the pastor or priest of a church are not exempt from property taxes." 250 Even though the church used the parsonage for some incidental church purposes, the court found that incidental church use did not meet the exclusive standard required by the state constitution. ${ }^{251}$

\section{Are Parsonages Exempt?}

Finally, four states do not explicitly exempt parsonages and courts have not adjudicated the question of exemption. Alabama exempts "all property, real and personal, used exclusively for religious worship." ${ }^{252}$ In Arizona, the religious property tax exemption applies to property "used or held primarily for religious worship." 253 Colorado exempts property "which is owned and used solely and exclusively for religious purposes." 254 Finally, the Kentucky Constitution exempts

245. Mount Zion New Life Ctr. v. Bd. of Assessment \& Revision of Taxes \& Appeals, 503 A.2d 1065, 1069 (Pa. Commw. Ct. 1986).

246. Id. at 1071 .

247. Connellsville St. Church of Christ v. Fayette Cnty. Bd. of Assessment Appeals, 838 A.2d 848, 850 (Pa. Commw. Ct. 2003).

248. UTAH CONST. art. XIII, $\S 3(1)(\mathrm{f})$.

249. Salt Lake Cnty. v. Tax Comm'n ex rel. Good Shepherd Lutheran Church, 548 P.2d 630, 631 (Utah 1976).

250. Id.

251. Id.

252. Ala. CODE $\S 40-9-1(1)$ (LexisNexis 2011).

253. Ariz. Rev. Stat. AnN. § 42-11109(A) (2018).

254. Colo. Rev. Stat AnN. § 39-3-106(1) (West 2019). 
"real property owned and occupied by, and personal property both tangible and intangible owned by, institutions of religion." 255

These four states' property tax exemptions for religious property are similar to the exemptions of other states without an explicit exemption for parsonages. Whether a parsonage is exempt under their laws depends, in general, on whether the state considers housing clergy a religious or secular use. As we have seen, the answer is not obvious. Without some sort of administrative or judicial determination, it is not clear whether parsonages in these four states qualify for the religious property tax exemption.

\section{B. Historic Differences in the Treatment of Parsonages}

While the current property tax treatment of parsonages by the various states illustrates that exempting parsonages is neither necessary nor inevitable, the historical significance test requires courts to look not only at the present, but also at the past. And, appropriately, the Seventh Circuit did not rest its historical significance analysis merely on states' present treatment of parsonages. Rather, the court held that the government, intervenors, and amici supporting the government had "provided substantial evidence of a lengthy tradition of tax exemptions for religion, particularly for church-owned property." 256 The varying approaches of current state laws demonstrates the degree to which this assertion brushes over the manner in which states analyze whether religiously owned property qualifies for exemption (which generally requires not only religious ownership, but also religious use).

The court's broad assertion also overlooks the historical variation in states' property tax. Currently, the vast majority of states either explicitly exempt parsonages or find that parsonages can, under some circumstances, fit within the scope of the religious property tax exemption. Even in those states that grant an exemption for parsonages, the history of that exemption is often not a clean, unbroken line back through history. In a number of states, the courts initially found that parsonages were not exempt, which conclusion was, in some cases, overturned by state legislatures in the early- to mid-twentieth century. Some jurisdictions even went through periods in which no religiously owned property qualified for property tax exemptions. These changes in tax treatment highlight that exemption was not inevitable and that history does not clearly lean in the direction of exemption.

If the Seventh Circuit is correct that the historical significance test is a proper Establishment Clause test to apply in looking at the constitutionality of the parsonage allowance, then we must actually look at the history of states grappling with the question of whether to exempt parsonages from the property tax. And that history demonstrates that, of the forty-four states and District of Columbia that clearly sometimes or always exempt parsonages from the property tax, thirteen have, at some point in the past, taxed parsonages. In most of these states, the law shifted to allow an exemption for parsonages in the early- to mid-twentieth century. These thirteen states represent about thirty percent of states that exempt parsonages from the

255. KY. CONST. $\S 170$.

256. Gaylorv. Mnuchin, 919 F.3d 420, 436 (7th Cir. 2019). 
property tax. That means that about three in ten of the states that exempt parsonages enacted that exemption relatively late in the Seventh Circuit's purported two centuries of states "implement[ing] church property tax exemptions in various forms." ${ }^{257}$ Moreover, because these changes occurred before the incorporation of the Establishment Clause, they have little relevance to the parsonage allowance's constitutionality. The remainder of this Part will discuss the states that disallowed property tax exemptions for parsonages at one point and now exempt them. ${ }^{258}$ It will divide the states (and the discussion) into three main categories: states that granted parsonages an exemption by amending their constitutions, states that granted parsonages an exemption legislatively, and states that granted parsonages an exemption judicially.

\section{Constitutional Change}

In four states, excluding parsonages from the property tax base required a constitutional change. In 1906, Minnesota became the first of these states to change its constitution. As early as 1867 , the state supreme court held that, under its property tax law, a "parsonage owned by a church is not exempt from taxation." ${ }^{259}$ A decade and a half later, the court explained that a parsonage was "clearly subject to taxation" because housing clergy was a secular, not a religious, use of property. ${ }^{260}$ By 1891 , the court held that the question of a property tax exemption for a parsonage had been answered so clearly that it was "therefore no longer open." 261

Then in 1906, Minnesota amended its constitution. While the amended constitution did not explicitly provide for the exemption of parsonages, it made two important changes to the exemption of religious property. First, it shifted from being a permissive exemption requiring implementing legislation to a self-executing provision. ${ }^{262}$ Second, it took language away from the provision. Where the constitution had previously provided for the exemption of "all churches, church property used for religious purposes, and houses of worship," after the amendment, the constitution provided for the exemption of "all churches, church property, and houses of worship." 263 The court held that the "omission of these words cannot be deemed to have been inadvertent or without a purpose." 264 Rather, it allowed churches to be treated the same way educational institutions were treated, including

257. Id.

258. The following discussion will leave out California and the District of Columbia, both of which eliminated all religious property tax exemptions for a period of time during the late nineteenth century. For a discussion of California and the District of Columbia, see supra Section III.A.2.

259. St. Peter's Church, Shakopee v. Bd. of Co. Comm'rs of Scott Cnty., 12 Minn. 395, 395 (1867).

260. In re Grace, 8 N.W. 761, 761 (Minn. 1881).

261. Ramsey Cnty. v. Church of the Good Shepherd, 47 N.W. 783, 783 (Minn. 1891).

262. State v. Church of Incarnation, 196 N.W. 802, 803 (Minn. 1924).

263. Id. at 803-04 (emphasis added).

264. Id. at 804 . 
allowing a property tax exemption for parsonages owned by a church and occupied by its pastor. ${ }^{265}$

Louisiana became the next of the four states to amend its constitution to grant a property tax exemption for parsonages owned by a religious organization. Nineteenth-century Louisiana embraced universal taxation with a general rule that all property was subject to the property tax. ${ }^{266}$ The state legislature exempted some classes of property from taxation, but only within the scope granted by the state constitution. ${ }^{267}$ The state supreme court held that "[t]he residence of the clergyman is in no proper or legitimate sense appurtenant to the church, and is not exempt from taxation," and therefore was not within the constitutional scope of a property tax exemption. ${ }^{268}$

In fact, the state's 1879 constitution exempted only two types of religious property from taxation: "places of religious worship or burial." 269 In its subsequent constitution, however, the state had expanded the scope of permissible religious exemptions from the property tax. Louisiana's constitutional expansion functioned differently from Minnesota's, though. The 1913 Louisiana Constitution provided for the exemption not only of places of religious worship or burial, but also "the rectories and parsonages of churches and grounds thereunto appurtenant, used exclusively as residences for the ministers in charge of such churches." ${ }^{270}$ Rather than making the list of constitutionally permissible exemptions broader generally, Louisiana specifically targeted parsonages for exemption.

Next came Texas. In its 1875 constitutional convention, state legislators focused on "[p]roviding for equal and uniform taxation." ${ }^{271}$ In part, that focus derived from "strong feeling[s] against exemptions previously granted by the legislature." 272 Similar to Louisiana's Constitution, the 1876 Texas Constitution's only exemption for religious property applied to "actual places of religious worship." 773 To ensure that future legislatures did not expand the constitutional list of permissible exemptions, the constitution further provided that "all laws exempting property from taxation other than the property above mentioned, shall be void." 274 In a 1906 amendment of the constitution, the legislature reemphasized its distrust of

265. Id. at 803-04.

266. First Presbyterian Church v. City of New Orleans, 30 La. Ann. 259, 260 (1878).

267. Id.

268. Id.

269. LA. CONST. of 1879 , art. 207.

270. LA. CONST. of 1913, art. 230.

271. City of Austinv. Univ. Christian Church, 768 S.W.2d 718, 721 (Mauzy, J., dissenting) (Tex. 1988).

272. George D. Braden, David A. Anderson, R. Stephen Bickerstaff, Darrell Blakeway, Ron Patterson, Seth S. Searcy, Thornton C. Sinclair \& Richard A. Yahr, The Constitution of the State of Texas: An Annotated and Comparative Analysis 565 (1977), https://www.sll.texas. gov/assets/pdf/braden/the-constitution-of-the-state-of-texas -an-annotated-and-comparative-analy sis.pdf [https://perma.cc/BV7Y-V8WZ].

273. TEX. CONST. of 1876 , art. VIII, $\S 2$.

274. Id. 
exemptions, driving "an unnecessary nail in the exemption coffin by providing that all other exemptions shall be not just void but null and void." 275

In 1918, a Texas court enforced the legislature's will, holding that a parsonage was not "used exclusively for 'public worship' or 'purely public charity,"' and therefore did not qualify for exemption from the property tax. ${ }^{276}$ In response, the legislature amended the state constitution. ${ }^{277}$ As of 1928, the Texas state constitution has provided that the legislature has the authority to exempt parsonages from the property tax. ${ }^{278}$

More than two decades later, Georgia became the fourth state to amend its constitution to permit parsonages to escape paying property tax. In 1887 , the state supreme court had explained that "[t]he property which belongs to a church is not exempt from taxation simply because it belongs to a church." ${ }^{279}$ In fact, the court wrote, not only was the parsonage in question not exempt from taxation, but the "legislature has no power to exempt it from taxation." ${ }^{280}$ Any attempt at exempting religious property other than places of public worship or burial (which were listed in the constitution) would be "simply void." 281

In 1927, the state supreme court used parsonages to illustrate the types of property not exempt under the state constitution. ${ }^{282}$ It was not until 1953 that the legislature proposed a voter resolution that would add the words "and all property owned by religious groups used only for residential purposes and from which no income is derived" to the list of permissible religious property tax exemptions. ${ }^{283}$ The voters ratified the amendment to the constitution in 1954, making Georgia the last of the four states to enact the constitutional change necessary to permit the legislature to exempt parsonages from the state property tax. ${ }^{284}$

\section{Legislative Change}

In five other states, a simple legislative change (without the need for any amendment of the constitution) sufficed to exempt parsonages. Of these states, New Jersey had perhaps the most interesting and convoluted experience shifting from not exempting parsonages to exempting them. In 1863, the state did not explicitly provide for the exemption of most religious property. The sole religious exemption

275. BRADEN ET AL., supra note 272, at 596.

276. Trinity Methodist Episcopal Church v. City of San Antonio, 201 S.W. 669, 670 (Tex. Civ. App. 1918), writ refused (Tex. Civ. App. 1919).

277. City of Austinv. Univ. Christian Church, 768 S.W.2d 718, 722 (Mauzy, J., dissenting) (Tex. 1988).

278. BRADEN ET AL., supra note 272, at 595-96.

279. Wardens of St. Mark's Church v. Mayor of Brunswick, 3 S.E. 561, 561 (Ga. 1887).

280. Id.

281. Id.

282. City of Columbus v. Muscogee Mfg. Co., 140 S.E. 860, 862 (Ga. 1927) ("So, while places of religious worship may be exempted, such exemption does not embrace a parsonage belonging to the church, in which the pastor or rector resides.").

283. H.R. 106-337j, 1953 Gen. Assemb., Nov.-Dec. Sess. (Ga. 1953).

284. Church of God of Union Assembly, Inc. v. City of Dalton, 119 S.E.2d 11, 13 (Ga. 1961). 
in its property tax was for "parsonages, with lots attached, not to exceed [\$5000]."285 In 1866, the state enacted legislation that superseded the prior exemptions. It expressly exempted "buildings erected and used for religious worship, and the land whereon the same are situate, necessary to the fair use and enjoyment thereof, not exceeding five acres for each one, the furniture thereof and the personal property used therein, [and] the endowment or fund of any religious society."286

While the 1866 law added buildings used for religious worship, it deleted language expressly exempting parsonages. When the First Reformed Dutch Church challenged the 1866 property tax assessment of a parsonage it owned, the New Jersey Supreme Court explained that the 1866 law superseded the 1863 law. ${ }^{287}$ According to the court, "if the legislature had intended to continue the exemption of parsonages, and to an unlimited value, it is not reasonable to believe that they would have left it to the mere construction that might be forced out of the word "endowment."'288

In the early $1870 \mathrm{~s}$, the New Jersey legislature started to exempt parsonages, not by general law, but by private laws. In 1873, it exempted the parsonage belonging to the Presbyterian congregation in Reaville and the parsonage belonging to the Reform Church in Middletown. ${ }^{289}$ It was not until 1903 that New Jersey reinserted in its property tax law an exemption for parsonages. ${ }^{290}$ The exemption was not absolute, though: it only exempted parsonages "owned by any religious corporation of this state while actually used by the officiating clergyman thereof," and only exempted parsonages up to a value of $\$ 5000 .^{291}$

As late as 1960, the New Jersey legislature deliberately enacted a law only exempting parsonages from the property tax to the extent of $\$ 5000 .{ }^{292}$ It was not until 1964 that New Jersey shifted from a limit on the value of exempt parsonages to a limit on the number of parsonages (two) and the acreage (five) of exempt parsonages that continues until today. ${ }^{293}$

Other states have been less dramatic in their shifts from nonexempt to exempt, but they have also used legislation to make that shift. In Indiana, for instance, the legislature had exempted "building[s] erected for religious worship." ${ }^{294}$ In 1871, the state supreme court held that, in spite of the "careful and mature consideration" it had given "to the very able and ingenious argument of the learned counsel for the appellants," it was "unable to see how we can, by construction, extend the statute so as to embrace parsonages that have been erected for the convenience and

285. Act of Mar. 25, 1863, ch. 278, § 2, 1863 N.J. LaWS 500, 502.

286. Act of Apr. 11, 1866, ch. 487, § 5(II), 1866 N.J. LAws 1078, 1079-80.

287. First Reformed Dutch Church of New Brunswick v. Lyon, 32 N.J.L. 360, 361 (1867).

288. Id.

289. Act of Feb. 26, 1873, ch. 101, 1 1, 1873 N.J. Laws 986, $986 \S 1$. Interestingly, in the late nineteenth century, a church selling its property-including its parsonage-required a general law enacted by the New Jersey legislature. See, e.g., Act of Mar. 28, 1895, ch. 350,

$\S 1,1895$ N.J. Laws $707,707$.

290. Act of Apr. 8, 1903, ch. 208, art. 1, § 4, 1903 N.J. Laws 394, 395.

291. Id.

292. Act of Sept. 7, 1960, ch. 119, § 1, 1906 N.J. Laws 618, 619.

293. Act of May 5, 1964, ch. 42, § 1, 1964 N.J. Laws 81, 82.

294. Methodist Episcopal Church v. Ellis, 38 Ind. 3, 7-8 (1871). 
accommodation of the pastor of the church."295 That power, it said, lay in the legislature. $^{296}$

Twenty years later, the legislature exercised that power. ${ }^{297}$ In 1891 , the Indiana legislature exempted buildings used for religious worship and "the parsonage attached thereto and occupied as such" from the property tax. ${ }^{298}$

In 1859, the Massachusetts consolidated general statutes provided for a tax on all real and personal property owned by state residents unless exempted by the law. ${ }^{299}$ The law provided for a number of exemptions, including "[h]ouses of religious worship, and the pews and furniture." ${ }^{300}$ Any part of exempt houses not used for religious worship, though, would be subject to the property tax at ordinary property tax rates. ${ }^{301}$

Did parsonages fit within the scope of the exemption? Massachusetts courts held that they did not. Exempting parsonages would certainly "aid in the support of public worship ..." but the legislature has not undertaken to exempt that which would do this, but the house of religious worship only." 302 Because the legislature had explicitly - and only-exempted those parts of houses of religious worship actually used for religious worship, parsonages did not qualify for the exemption.

In 1938, the Massachusetts legislature amended its exemption. Houses of religious worship remained exempt to the extent they were used for religious worship, but the legislature added an exemption "to an amount not exceeding five thousand dollars for each parsonage." ${ }^{303}$ Five years after its enactment, the courts affirmed a religious organization could own more than one parsonage and that the $\$ 5000$ exemption applied to each parsonage separately. ${ }^{304}$

In the nineteenth century, Rhode Island law also exempted property used exclusively for religious purposes ${ }^{305}$ The state supreme court found that parsonages did not qualify for exemption under this law. ${ }^{306}$ Even using one room of the parsonage for religious worship did not convert the character of the parsonage into a building used for religious worship. ${ }^{307}$ It took until almost halfway through the twentieth century for Rhode Island to amend its property tax exemption to include

295. Id. at 9.

296. Id.

297. See Oak Hill Cemetery Co. v. Wells, 78 N.E. 350,351 (Ind. App. 1906)

298. Act of Mar. 6, 1891, ch. XCIX, § 5, 1891 Ind. Acts 199, 200-01.

299. Act of Feb. 3, 1859, tit. III, ch. 11, § 2, 1859 Mass. Acts 227, 227.

300. Id. $\S 5$.

301. Id.

302. Third Congregational Soc'y v. City of Springfield, 18 N.E. 68, 69 (Mass. 1888).

303. Act of May 16, 1938, ch. 317, 1938 Mass. Acts 270, 270. It is worth noting that, notwithstanding its name, the General Court of Massachusetts is the state legislature. MAss. ConsT. pt. 2, ch. I, $\S 1$, art. I ("The department of legislation shall be formed by two branches, ... and shall be stiled [sic], The General Court of Massachusetts.") (emphasis omitted).

304. Assessors of Bos. v. Old S. Soc'y, 50 N.E.2d 51, 52-53 (Mass. 1943).

305. Act of Feb. 1, 1882 tit. VIII, ch. 41, § 2, 1882 R.I. Pub. Laws, 120, 120.

306. St. Joseph's Church v. Assessors of Taxes of Providence, 12 R.I. 19, $20-21$ (1878).

307. Id. 
parsonages. ${ }^{308}$ And when it included parsonages, it limited the exempt value of a parsonage to $\$ 10,000 .^{309}$

Idaho made a similar legislative change, though the reasons for the change are unclear. When Idaho became a state, it "carr[ied] over the language of the territorial statute exempting religious property into the law of the state." 310 Similar to many other states, the territorial (and then state) law exempted "[c]hurches, chapels and other buildings with the lots or ground appurtenant thereto and used therewith, belonging to any church organization or society and used for religious worship."311 No cases explicitly adjudicate the question of whether this exemption included parsonages, but two things suggest that it did not. First, Idaho courts construe tax exemptions narrowly and strictly against the taxpayer. ${ }^{312}$ The language of the statute required that exempt buildings be used for religious worship. Residence is not worship, and other states that dealt with the question held that, where the exemption statute required religious worship, parsonages did not qualify.

Second, in 1913, Idaho changed its law. ${ }^{313}$ While the impetus for the change is unclear, the result is perfectly clear. Under the 1913 law, the tax exemption applied not only to buildings owned by religious entities and used for public worship, but also to "any parsonage belonging to such corporation or society and occupied as such." 314 Whatever the legislature's motivation in doing so, like the other states discussed in this Section, it explicitly legislated an exemption for parsonages. ${ }^{315}$

308. Act of Jan. 15, 1947, ch. 1855, 1947 R.I. Pub. Laws 1, 87.

309. Id.

310. Corporation of Presiding Bishop of Church of Jesus Christ of Latter-Day Saints v. Ada Cnty., 849 P.2d 83, 88 (Idaho 1993).

311. Act of Mar. 7, 1911, ch. 171, sec. 1, § 1644, 1911 Idaho Sess. Laws 565, 566.

312. Corporation of the Presiding Bishop of the Church of Jesus Christ of Latter-Day Saints, 849 P.2d at 88 .

313. Id.

314. Act of Mar. 13, 1913, ch. 58, art. I, §4(B), 1913 Idaho Sess. Laws 173, 175.

315. It is worth noting that even this change did not bring absolute clarity to the question of the exemption of parsonages. While the legislature clarified that parsonages were exempt from taxation, it did not clarify what qualified as a parsonage. In 1991, the state supreme court looked at whether the home of a Mormon mission president qualified as a parsonage for purposes of the property tax exemption. Corporation of the Presiding Bishop of the Church of Jesus Christ of Latter-Day Saints, 849 P.2d at 87. In applying its narrow construction, see supra note 312 and accompanying text, it determined that "parsonage" meant "a residence occupied by the incumbent minister having ecclesiastical domain over a contained body of parishioners or church members, formally referred to as a congregation." Id. at 90 . Because a Mormon mission president did not have an affiliated meetinghouse or a local congregation, and because a Mormon mission president did not function as a minister, the home he lived in did not qualify as a parsonage for property tax exemption purposes. $I d$. at 92.

In 2007, the Idaho legislature again updated its property tax exemptions. Under the 2007 law, instead of exempting parsonages, Idaho exempted property owned by religious societies "including any and all residences used for or in furtherance of such purposes." Act of Mar. 2, 2007 , ch. 38, § 1, 2007 Idaho Sess. Laws 95, 95. The legislature explained that it was replacing the word "'parsonages,' which has caused much confusion," with the new broader language, "which properly reflects the types of usages meant to be exempt." H. Res. $16748,59 \mathrm{Leg} ., 1$ st Sess. (Idaho 2007). 


\section{Judicial Change}

Two states comprise the third category, in which the exemption of parsonages occurred through judicial decisions rather than amendments to the state constitution or state statutes. Like Idaho, in 1895, Oregon's supreme court held that tax exemptions were strictly construed against the taxpayer, and to claim an exemption, the legislature's intent to grant it had to be "clear beyond a reasonable doubt." 316 Although the property in front of the Oregon Supreme Court was not a parsonage, the court used a parsonage as an example of the type of property that would not qualify as exempt from taxation. ${ }^{317}$

More than eighty years later, taxpayers seem to have internalized the court's dicta. In 1976, the Skyline Assembly of God acknowledged that the portion of its property it used as a parsonage did not qualify for a property tax exemption. ${ }^{318}$ It argued that its use of the rest of its property did qualify for exemption, though, because it used the rest of the property for religious purposes. ${ }^{319}$

It took until the following year for the question of whether a parsonage qualified for tax exemption to land squarely in front of the Oregon court. ${ }^{320}$ And when the question landed squarely in front of the court, it chose not to follow its previous dicta entirely. Instead, it held that if the property owner showed that it needed a parsonage to accomplish a religious purpose and that because its actual use was to accomplish religious purposes, a parsonage could qualify as exempt. Parsonages, under Oregon judicial precedent, do not automatically qualify as exempt. But, the court said, with appropriate needs and uses, they can. ${ }^{321}$

Illinois presents perhaps the most complex case of all of the states whose law changed to allow the exemption of parsonages. The 1870 state constitution required that the legislature levy a tax under which "every person and corporation shall pay a tax in proportion to the value of his, her, or its property." ${ }^{322}$ The constitution allowed, but did not require, the legislature to exempt from that general property tax property "used exclusively for . . religious . . purposes." 323 The legislature could only create these exemptions through general law. ${ }^{324}$

Two years later, the Illinois legislature enacted legislation creating a general property tax that applied to, among other things, "[a]ll real and personal property in this state." ${ }^{25}$ The statute took advantage of the constitutionally permitted

316. Portland Hibernian Benevolent Soc'y v. Kelly, 42 P. 3, 6 (Or. 1895).

317. Id.

318. Skyline Assembly of God v. Dep't of Revenue, 545 P.2d 879, 880 (Or. 1976).

319. Id.

320. German Apostolic Christian Church v. Dep't of Revenue, 569 P.2d 596, 599 (Or. 1977) ("We have not in the past directly ruled on the taxability of a church rectory or parsonage.").

321. See id. at 600.

322. ILL. CONST. of 1870 , art. IX, $\S 1$.

323. Id. $\S 3$.

324. Id.

325. Act of Mar. 30, 1872, ch. 120, § 1, 1872 Ill. Laws 1620, 1624. 
exemptions, removing, among other things, "[a]ll property used exclusively for religious purposes" from the property tax base. ${ }^{326}$

In 1905, the Illinois legislature amended its property tax exemptions, adding parsonages to the list of property exempt from the property tax ${ }^{327}$ In 1907, the Cook County tax collector sued the First Congregational Church of Oak Park for unpaid property taxes on a two-story home owned by the church and used exclusively by the pastor and his family as a residence. ${ }^{328}$

The Illinois Supreme Court held that a home used "primarily for a family residence by the pastor" was not used "exclusively for religious purposes," 329 the constitutional requirement for a property tax exemption. Moreover, in spite of its attempt, the court held that the legislature could not "make that a religious purpose which in fact is not a religious purpose." ${ }^{330}$ Because housing clergy did not qualify as a religious purpose, church-owned parsonages in Illinois were subject to the property tax. ${ }^{331}$

Five years later, the court revisited the question of parsonage tax exemptions. The pastor of the First Congregational Church of DeKalb lived with his family in a church-owned parsonage. ${ }^{332}$ The pastor testified that not only did he and his family live in the parsonage, but that he also used the parsonage for a number of religious purposes, including counselling congregants, performing marriages and baptisms, and sometimes even holding classes and Sunday school. ${ }^{333}$

The Illinois Supreme Court held that the parsonage did not qualify for an exemption from the property tax despite these incidental religious uses. ${ }^{334}$ Under a general property tax, it noted, all property is taxable unless exempted from taxation by the state constitution and statutes consistent with the state constitution. ${ }^{335}$ "And in determining whether property falls within the terms of the exemption, whether it be constitutional or statutory, it is the primary use to which the property is put which must be considered and not its secondary use." 336

The court found that, in spite of the various incidental uses of the parsonage, its primary use was housing the pastor and his family ${ }^{337}$ Housing the pastor was a

326. Id. $\S 2$.

327. People ex rel. Thompson v. First Congregational Church of Oak Park, 83 N.E. 536, 537 (IIl. 1907).

328. Id.

329. Id. at 538 .

330. Id.

331. Id.

332. First Congregational Church of De Kalb v. Bd. of Review of De Kalb Cnty., 98 N.E. 275, 275 (Ill. 1912).

333. Id.

334. Id. at 277 .

335. Id. at 276 .

336. Id. (citing People ex rel. Thompson v. First Congregational Church of Oak Park, 83 N.E. 536, 538 (11l. 1907)).

337. Id. at $276-77$. 
secular, not religious, purpose. ${ }^{338}$ In 1912 , then, parsonages in Illinois continued to be subject to the state's general property tax. ${ }^{339}$

In 1957, the Illinois legislature tried again to exempt parsonages from the property tax. It amended the Revenue Act of 1939 to exempt

[a]ll property used exclusively for religious purposes, ... including all such property owned by churches or religious institutions and used in conjunction therewith as parsonages or other housing facilities provided for ministers, their spouses, children and domestic employees, performing the duties of their vocation as ministers at such churches or religious institutions. ${ }^{340}$

Kurt McKenzie, an Illinois taxpayer, challenged the exemption for parsonages as being unconstitutional under the Illinois Constitution. ${ }^{341}$ His argument for its unconstitutionality roughly followed the Illinois Supreme Court's early twentiethcentury cases: parsonages were used primarily for secular purposes and therefore were not used exclusively for religious purposes. ${ }^{342}$

Essentially, McKenzie argued that the Illinois Constitution created a blanket ban of exempting parsonages because a parsonage's "residential character must predominate over any other religious uses of the property." 343 The court disagreed. It had a long history of reading the exclusivity requirement of property tax exemption as requiring that a property's primary purpose be exempt. ${ }^{344}$ Parsonages, it held, were no different in this regard. ${ }^{345}$

But the court did highlight a significant difference between McKenzie's case and the earlier cases denying parsonages a tax exemption. The narrow construction of primary religious use, it explained, "is out of step with more recent Illinois authority on tax exemptions, and these cases do not establish that parsonages may never be used exclusively — that is primarily — for religious purposes." ${ }^{346}$ Under contemporary

338. Id. at 277. It is worth noting, as we explore the convoluted history of the parsonage property tax exemption, that the Illinois Supreme Court's conclusion was not inevitable. Around the same time, South Dakota's constitution exempted religious property with language identical to that found in the Illinois Constitution. State ex rel. Eveland v. Erickson, 182 N.W. 315, 318 (S.D. 1921). The South Dakota Supreme Court adopted the reasoning of the dissenters in First Congregational Church of De Kalb v. Board of Review of De Kalb County, 98 N.E. 275, 278 (Ill. 1912): the exclusivity requirement meant the property was used primarily for religious purposes, and that housing clergy was a religious purpose. Id. at 319 . Thus, with an identical constitution and a substantially identical fact pattern, the South Dakota Supreme Court allowed for the exemption of parsonages where the Illinois Supreme Court did not.

339. See First Congregational Church of De Kalb, 98 N.E. at 226

340. Act of July 13, 1938, § 19, 1938 Ill. Laws 66 (codified as amended at Act of June 13, 1957, sec. $1, \S 19,1957$ Ill. Laws 614, 615).

341. McKenzic v. Johnson, 456 N.E.2d 73, 75 (Ill. 1983)

342. Id. at $76-77$.

343. Id. at 78 .

344. Id.

345. Id. at $78-79$

346. Id. at 79 . 
standards, the court looks to whether the property "reasonably and substantially facilitates the aims of religious worship or religious instruction." 347

The Illinois Supreme Court emphasized in its McKenzie decision that the inclusion of parsonages in the statute does not mean parsonages inherently qualify as exempt. Rather, the inclusion of parsonages in the statute illustrates "one type of property that, under appropriate circumstances, may qualify for the general religious property exemption." ${ }^{348}$ Because the 1957 legislation did not expand the set of exempt religious property beyond the state constitution-and because judicial definitions of exclusivity expanded-by 1957, Illinois had shifted from refusing to exempt parsonages to accepting parsonages as exempt from the property tax under many circumstances. ${ }^{349}$

\section{THE WRONG History}

While a careful review of the history of property tax exemptions for parsonages demonstrates that the Seventh Circuit misunderstood the history, even if it had portrayed the history correctly that history would not lend support to the idea that income tax exemptions for housing allowances met the historical significance test. A property tax exemption differs from an income tax exclusion, both substantively and constitutionally. Moreover, the beneficiary of the income tax exclusion differs from the beneficiary of the property tax exemption.

The Western District of Wisconsin noticed this distinction between a property and an income tax. The district court opinion pointed out that the history the intervenors relied on was the history of church property tax exemptions. ${ }^{350}$ The court stated that it "cannot generalize that all religious tax exemptions are permissible simply because one type of exemption has historical support." 351

The district court raised a critical point. In Town of Greece v. Galloway, the Supreme Court dismissed the need to define "the precise boundary of the Establishment Clause where history shows that the specific practice is permitted."352 The historical significance test requires this specificity precisely because it relies on the Framers' acceptance of the practice, as well as it subsequently withstanding "the critical scrutiny of time and political change." 353

If the Supreme Court's jurisprudence actually requires the specific practice, even if states had consistently exempted parsonages from property tax, that would not reflect on the constitutionality of an income tax exclusion. And, in fact, income tax exemptions could never pass the historical significance test, since the first time the

347. Id.

348. Id. at 77.

349. See Act of July 13, 1938, $\S 19,1938$ Ill. Laws 66 (codified as amended at Act of June 13, 1957, sec. 1, § 19, 1957 Ill. Laws 614, 615); McKenzie, 456 N.E.2d at 100.

350. Gaylor v. Mnuchin, 278 F. Supp. 3d 1081, 1102 (W.D. Wis. 2017), rev'd, No. 16CV-215-BBC, 2017 WL 6375819 (W.D. Wis. Dec. 13, 2017), rev'd, 919 F.3d 420 (7th Cir. 2019).

351. Id. at 1103.

352. 572 U.S. 565,577 (2014).

353. Id. 
country implemented a federal income tax was during the Civil War and the second time was in $1913 .{ }^{354}$

How does the Seventh Circuit deal with this problem? It denies that there is a problem, asserting that the difference between property tax and income tax is "too fine a distinction" to matter. ${ }^{355}$ And it is too fine a distinction, according to the Seventh Circuit, precisely because "[b]efore 1913, Congress could not constitutionally tax housing provided to ministers as part of their income." 356 The court implicitly acknowledges that the income tax, standing on its own, is not amenable to a historical significance test, and thus it has to import two centuries of property tax to force the question to fit within the historical significance test framework.

This move, while necessary for the court to apply its historical significance test, does not work. The history, policy, and constitutional considerations surrounding property taxes differ too much from the same history, policy, and constitutional considerations that apply to the income tax.

Critically, income taxes and property taxes are not functionally equivalent. Some differences reflect practical concerns. Property taxation is a subset of wealth taxation, ${ }^{357}$ in contrast to income taxation, which is not. Property and income taxation are "not the same in substance." 358 A property tax is imposed on the assessed value of the property, and is due whether or not the owner has liquid assets with which to pay the tax. ${ }^{359}$ The federal income tax, by contrast, is imposed on net income, ensuring taxpayers have some degree of liquidity with which to pay the $\operatorname{tax}^{360} \mathrm{In}$ essence, then, a taxpayer can owe property tax even when she has no income with which to pay the property tax. By definition, though, she cannot owe income tax unless she has income.

Popular perception of income and property taxes reflects this difference. Because of the different bases of the two taxes (income versus assessed value of the property), they may have "different political optics." 361 And historically, the two have had different constitutional optics. For instance, in 1969, William Consedine, general counsel of the U.S. Catholic Conference, argued to the Senate that "fiscal separation" was fundamental to the separation of church and state. ${ }^{362}$ According to Consedine,

354. See supra note 11.

355. Gaylor v. Mnuchin, 919 F.3d 420, 436 (7th Cir. 2019).

356. Id.

357. Joseph Bankman \& Daniel Shaviro, Piketty in America: A Tale of Two Literatures, 68 TAX L. REv. 453, 489 (2015) ("A conventional wealth tax would be a property tax-albeit, more broad-based than those generally applied by the states if it included financial wealth.").

358. Joseph M. Dodge, What Federal Taxes Are Subject to the Rule of Apportionment Under the Constitution?, 11 U. PA. J. ConST. L. 839, 932 (2009).

359. See Stewart E. Sterk \& Mitchell L. Engler, Property Tax Reassessment: Who Needs It? 81 Notre Dame L. Rev. 1037, 1045 (2006); Edward A. Zelinsky, The Once and Future Property Tax: A Dialogue with My Younger Self, 23 CARdOzo L. REv. 2199, 2201-02 (2002).

360. See David A. Weisbach, The (Non)taxation of Risk, 58 TAX L. REV. 1, 36 (2004) ("Income tax advocates would prefer a Haig-Simons system but because of liquidity, valuation, or other problems, we have a realization system.").

361. Bankman et al, supra note 357, at 488.

362. Bernard D. Reams, JR., TAX Reform-1969: A Legislative History of the TAX ReForm ACt OF 1969 (Public LaW 91-172) With Related AMENDMENTS 4435 (1991). 
that fiscal separation did not mean that religion was exempt from tax. In fact, "[w]here the tax is imposed on property and not directly on religious activities, Government has wide discretion under our Constitution to impose or not to impose the tax." 363

These different constitutional optics may reflect actual constitutional differences. While the courts recognize property taxes as direct taxes subject to constitutionally mandated apportionment, ${ }^{364}$ the Sixteenth Amendment expressly permits Congress to impose income taxes without apportioning them. ${ }^{365}$ Moreover, an emerging (though not universal) consensus believes that the Supreme Court overreached in its Pollock decision, which found the income tax unconstitutional. ${ }^{366}$ If this consensus is right, the Sixteenth Amendment was superfluous because, unlike taxes on real property, taxes on income do not fall within the scope of direct taxes.

Given these structural and constitutional differences, there is no plausible justification for the Seventh Circuit's assertion that differences between income and property taxes were "too fine" to have constitutional relevance ${ }^{367}$ Even assuming that there were justifications for using the history of property tax exemptions to explore the constitutionality of an income tax exclusion, though, state property tax exemptions for religiously owned property provide no information about what the Framers thought of the permissibility of these exemptions.

The court was correct that the Framers could not have considered the constitutionality of exempting ministers from an income tax on housing allowances when they wrote the Constitution, because the United States would not enact a federal income tax for nearly seventy-five years after they enacted the Constitution. But they were also not thinking about the constitutionality of exempting church property from a property tax. In fact, they most likely did not consider the contours of a property tax at all.

The Constitution gave Congress the "Power To lay and collect Taxes, Duties, Imposts and Excises." 368 It limited that power, though, with respect to direct taxes. Under the Constitution, "No Capitation, or other direct, Tax shall be laid, unless in Proportion to the Census or Enumeration herein before directed to be taken." 369 This apportionment of direct taxes, along with determining representation in the House, was part of the Three-Fifths Compromise that inserted inequality directly into the Constitution and bridged a divide between northern and southern states. ${ }^{370}$

363. Id.

364. See supra notes $358-62$ and accompanying text.

365. U.S. CONST. amend. XVI.

366. Johnsen et al., supra note 129, at 114, 119 ("Furthermore, most (but not all) commentators are extremely critical of the Court's decision in Pollock, recognize the practical impossibility in modern times of apportioning just about any plausible tax, and endorse some narrow construction of this limitation on Congress's otherwise-broad constitutional authority.").

367. Gaylor v. Mnuchin, 919 F.3d 420, 436 (7th Cir. 2019).

368. U.S. ConST. art. I, $\S 8$, cl. 1.

369. Id. art. I, $\S 9, \mathrm{cl} .4$.

370. Robin L. EInHorn, American TaXation, American Slavery 165-66 (2006). 
The problem with this bridge was that nobody knew precisely what constituted a direct tax. ${ }^{371}$ Whatever the scope of a direct tax was, though, there was broad consensus that it included taxes on real property. Alexander Hamilton believed that indirect taxes were made up largely of "duties and excises on articles of consumption," while direct taxes included taxes on real property. ${ }^{372}$ And in 1796, a majority of the Supreme Court wrote in their opinions in Hylton that direct taxes included taxes on land. ${ }^{373}$

Effectively, requiring Congress to apportion direct taxes meant that Congress would generally not impose direct taxes. Apportioning a tax on real property would require each state to pay the percentage of the tax that corresponded to the percentage of the country's population that lived in the state. More populous states would face a higher tax burden, irrespective of the value of the land in the state. ${ }^{374}$

The apportionment requirement did not make a federal property tax impossible. It did ensure its unlikeliness, though. The Framers expected that Congress would enact direct taxes rarely, if at all. ${ }^{375}$ In fact, the federal government only enacted direct taxes four times: "once in 1798, twice during the War of 1812, and once during the Civil War." 376

In crafting these federal property taxes, the federal government had to comply with the Establishment Clause ${ }^{377}$ For the first 150 years of the Constitution, though, the courts gave virtually no guidance as to what such compliance looked like. ${ }^{378}$ Similarly, these federal property taxes provide no information about the Framers' thoughts on exemptions for religiously owned property generally, or for parsonages in particular. Each of the statutes provides for a direct tax on, among other things, all lands, dwelling-houses, and enslaved persons located within a state. ${ }^{379}$ These direct taxes provided exemptions for property owned by the United States, by the states, and for property exempted under the law of the respective state. ${ }^{380}$ States, in turn, had not yet implemented universal property taxes. As a result, their property tax exemptions were ad hoc and largely carried over from their colonial history. ${ }^{381}$

371. Bruce Ackerman, Taxation and the Constitution, 99 Colum. L. REv. 1, 4 (1999) ("Within this context, the fact that the nature of 'direct' taxation was lost in a haze of uncertainty was not a vice-it helped the contending parties to patch together a verbally attractive compromise, and to turn their attention to more profitable subjects of conversation.").

372. The Federalist No. 36, at 174 (Alexander Hamilton) (Ian Shapiro ed., 2009).

373. Hylton v. United States, 3 U.S. (3 Dall.) 171, 175-76, 183 (1796).

374. Cf. Samuel D. Brunson, Paying for Gun Violence, 104 MinN. L. REv. 605, 628 (2019) (describing hypothetical example of an unfair apportioned direct tax).

375. EINHORN, supra note 370 , at 165.

376. Id. at 158 .

377. Zelman v. Simmons-Harris, 536 U.S. 639, 678 (2002) (Thomas, J., concurring) ("The Establishment Clause originally protected States, and by extension their citizens, from the imposition of an established religion by the Federal Government.").

378. BRUNSON, supra note 23, at 14.

379. Act of July 14,1798 , ch. $75, \S 2,1$ Stat. 597,598 ; Act of July 22,1813 , ch. $16, \S 5,3$ Stat. 22, 26; Act of Jan. 9, 1815, ch. 21, § 5, 3 Stat. 164, 166; Act of Aug. 5, 1861, ch. 45, $\S 13,12$ Stat. 292, 297.

380. $\S 2,1$ Stat. at $598 ; \S 5,3$ Stat. at $26 ; \S 5,3$ Stat. at $166 ; \S 13,12$ Stat. at 297.

381. See supra notes $158-60$ and accompanying text. 
If federal property tax does nothing to help us understand how the Framers viewed the constitutionality of property tax exemptions for parsonages, looking at state-level property tax exemptions does little more. In the first instance, the Establishment Clause applied only to the federal government, and created no impediment to states favoring religion if they so chose. ${ }^{382}$ In the second, state legislatures did not initially approach property taxes systemically. ${ }^{383}$ When they finally did, they evinced significant skepticism about exemptions from the property tax, and even when legislatures permitted exemptions for religious property, they crafted those exemptions narrowly, often in ways that excluded parsonages. ${ }^{384}$

Finally, and most importantly, even if the history of federal or state property tax exemptions provided any insight into the Framers' views - as the historical significance test mandates ${ }^{385}$ - that history proves utterly irrelevant to the question the Seventh Circuit addressed. The question before the court was not about the constitutionality of providing tax-free housing to clergy. While the taxpayers originally challenged the constitutionality of this in kind allowance, the district court dismissed that portion of the challenge, and the taxpayers did not appeal its dismissal. ${ }^{386}$ The only question in front of the court was whether the Constitution allowed the government to exclude cash housing allowances paid to clergy from the clergy's income. ${ }^{387}$

Naturally, clergy did not - and do not - pay property tax on their income. Neither do other taxpayers. By definition, a property tax does not apply to taxpayers' income-its base is the assessed value of the taxpayers' property, not their income. ${ }^{388}$ As a result, state property tax laws could not reach housing allowances.

Moreover, even if a court were to stretch analogy beyond the breaking point, property tax exemptions provide no support for excluding cash allowances that allow clergy to rent or buy their own homes. In every state that permits an explicit exemption for parsonages, the law requires that the parsonage be owned by a religious organization, not by individual clergy. ${ }^{389}$ Similarly, in other states without an explicit exemption for parsonages, only religiously owned property can qualify for the exemption. ${ }^{390}$

382. See supra notes 135 and accompanying text.

383. See supra notes $158-59$ and accompanying text.

384. See supra notes 161-64 and accompanying text.

385. See supra note 115 and accompanying text.

386. Gaylor v. Mnuchin, 919 F.3d 420, 425 (7th Cir. 2019).

387. See id. at 424-25 ("In response, Gaylor and Barker filed amended tax returns for 2012 and 2013 claiming refunds for their housing allowances under $\S 107(2)$; Nicol Gaylor did the same for 2013.").

388. Kenneth A. Stahl, The Challenge of Inclusion, 89 TEMP. L. REV. 487, 498 (2017) (" $[T]$ he local property tax base ... is determined by the assessed value of homes in the community.").

389. See supra Section IV.A.1.

390. See supra Section IV.A.2-3. New York State provides the one exception to this rule; in New York, clergy can exclude up to $\$ 1500$ of property annually from the property tax. N.Y. REAL PROP. TAX $\$ 460$ (1) (McKinney 2017). Even this exception to the general rule provides no support for the constitutionality of the parsonage allowance-the exemption, whether or not constitutional, is both insufficient to substantively cover housing costs and it applies broadly to all taxable property, irrespective of type or use. 
Ultimately, then, even if the history of state property tax exemptions for parsonages provided a clean and consistent history, that history would have nothing to say about whether an income tax exclusion for housing allowances paid to clergy comported with the Establishment Clause. Income taxes and property taxes differ substantively and constitutionally. Beyond that difference, because the Establishment Clause did not apply to states, their property taxes and exemptions did not have to comply with constitutional limitations on the establishment of religion. And on those rare occasions when the federal government looked to direct taxation, it ignored questions of religious property altogether, instead adopting whatever exemptions the various states recognized.

\section{CONCLUSION}

An in-depth look at the history of state property tax exemptions for parsonages is illuminating. It demonstrates shifts in state policy underlying both property taxes and exemptions from property tax. This history shows that exempting parsonages is not an inevitable policy choice, and even when a state exempts parsonages, the state often imposes limits on that exemption. Those limits range from all states limiting the exemption to parsonages owned by religious organizations to some states limiting the acreage, value, or number of exempt parsonages.

This historical analysis does not illuminate that the parsonage allowance is consonant with the Establishment Clause. Admittedly, the history also does not show that the parsonage allowance violates the Establishment Clause. However, the federal government has rarely enacted property taxes, and the Establishment Clause was incorporated against the states relatively recently. As a result, the question of establishment was not one that states generally grappled with. Instead, the constitutional question many states had to deal with was whether parsonages met the state constitution's requirement for a religious tax exemption, which often turned on whether housing clergy qualified as a religious purpose. This is an important question, but one with no relevance to whether the federal exclusion of housing allowances to clergy violates the Establishment Clause.

Even if the history of property tax exemptions provided a clear case for or against the constitutionality of the federal parsonage allowance, though, this Article demonstrates that the Seventh Circuit's use of that history in Gaylor was deeply deficient. The Seventh Circuit asserted-inaccurately—an unbroken, consistent history of exemptions for religious property and used that history to assume a similarly unbroken history of exemptions for parsonages.

The consistent history the Seventh Circuit asserted is entirely imaginary. The policy for exempting religious property from the property tax has shifted substantially over the last two centuries and was controversial even in its earliest days. In fact, both California and the District of Columbia had periods during the nineteenth century when they did not exempt religious property.

And history demonstrates that the exemption for religious property has always been narrower than all property owned by a religious organization. All states have required that exempt property be owned by the religious organization, and most states have required that it either be used for religious purposes (or, in some cases, worship) or otherwise be explicitly listed to qualify for an exemption from the property tax. 
The Seventh Circuit elided all of this complexity and inconsistency in the one page of its opinion it dedicated to evaluating the history of property tax exemptions for parsonages. ${ }^{391}$ Instead, it posited a clean, orderly, consistent history, with "a lengthy tradition of tax exemptions for religion, particularly for church-owned properties." ${ }^{392}$ While the purported history the Gaylor court relied on was clean and easy to understand, this Article has demonstrated both that there is no singular lengthy tradition of tax exemptions for religion, and that even if there were, "churchowned properties" is far too broad a category. Moreover, its opinion entirely missed the fragility of property tax exemptions for parsonages.

The problem here is not merely a deficient Seventh Circuit opinion, though that is a problem. In general, this Article should give pause to the idea that a historical significance test is a viable test for Establishment Clause questions. A historical argument is not a legal argument, and there is no reason to believe that attorneys or judges have the skills necessary to make or adjudicate a historical argument well. ${ }^{393}$ Gathering and reviewing the history of a law that may privilege religion is a long and complicated undertaking. It is both interesting and important but may be an undertaking better left to the academy than to judicial proceedings. If courts truly want to use a historical significance test, they need to engage fully with the history, not use a subset of the history as a justification to arrive at the result they want.

The Supreme Court's Establishment Clause jurisprudence is a mess. But adding a poorly conceived and poorly done historical analysis to the mix of jurisprudential tools does little to clarify and improve the Establishment Clause landscape. As the Seventh Circuit's Gaylor opinion and this Article demonstrate, unless courts are willing to put in an inordinate amount of work and analysis, they should avoid the historical significance test, and instead use tools better fit to legal analysis.

391. See Gaylor v. Mnuchin, 919 F.3d 420, 436 (7th Cir. 2019).

392. Id.

393. Judges and attorneys do make historical arguments, of course. But should they? "An obvious objection is that judges (and presumably lawyers) are poor historians." Jonathan C. Lipson \& Jennifer L. Vandermeuse, Stern, Seriously: The Article I Judicial Power, Fraudulent Transfers, and Leveraged Buyouts, 2013 WIS. L. REv. 1161, 1223 (2013). This is not necessarily an indictment of judges and attorneys: while legal scholarship and historical scholarship share similar ancestral roots, "their professional paths have long since diverged in many ways." Mark J. Osiel, Ever Again: Legal Remembrance of Administrative Massacre, 144 U. PA. L. REV. 463,524 (1995). More cynically, Judge Richard A. Posner wrote that " $[t]$ he legal profession's use of history is a disguise that allows the profession to innovate without breaching judicial etiquette, which deplores both novelty and a frank acknowledgement of judicial discretion and likes to pretend that decisions by nonelected judges can be legitimated by being shown to have democratic roots in some past legislative or constitutional enactment." Richard A. Posner, Past-Dependency, Pragmatism, and Critique of History in Adjudication and Legal Scholarship, 67 U. CHI. L. REv. 573, 581 (2000). 


\section{APPENDIXES}

APPENDIX 1: STATES WITH EXPRESS STATUTORY EXEMPTIONS FOR PARSONAGES

\begin{tabular}{|c|c|}
\hline State & Statutory Exemption \\
\hline Alaska & ALASKA STAT. ANN. $\S 29.45 .030(b)(2018)$ \\
\hline Arkansas & ARK. CODE ANN. §26-3-206(2020) \\
\hline Connecticut & CONN. GeN. STAT. ANN. $§ 12-81(15)$ (West 2019) \\
\hline District of Columbia & D.C. CODE ANN. $\S 47-1002(15)(2015)$ \\
\hline \begin{tabular}{l|l} 
Florida & \\
\end{tabular} & FLA. STAT. ANN. § 196.011(b)(3) (West 2014) \\
\hline Georgia & GA. CODE ANN. $\S 48-5-41(a)(3)(2017)$ \\
\hline Hawaii & 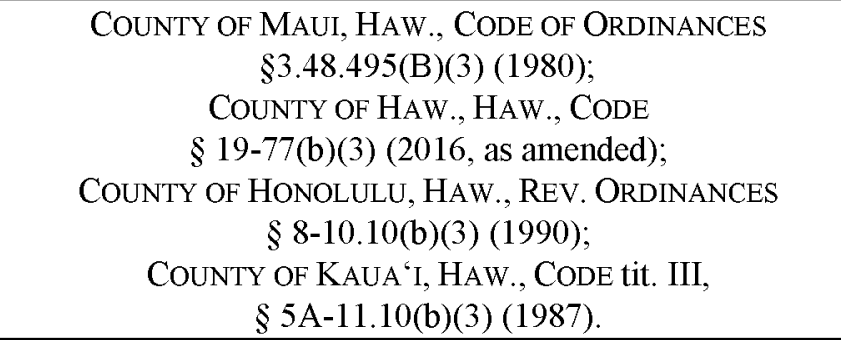 \\
\hline Idaho & IDAHO CODE ANN. § 63-602B (West 2017) \\
\hline Illinois & 35 ILL. COMP. STAT. 200/15-40(b) (2016) \\
\hline Indiana & IND. CODE $\S 6-1.1-10-21(\mathrm{~b})$, (c) (West 2013) \\
\hline Kansas & KAN. STAT. ANN. § 79-201 (West 2018) \\
\hline Maine & ME. REV. STAT. tit. $36, \S 652(1)(\mathrm{G})(2010)$ \\
\hline Maryland & MD. CODE ANN., TAX-PROP. $§ 7-204(2)$ (LexisNexis 2018) \\
\hline Massachusetts & MASS. GEN. LAWS ANN. ch. 59, $\S 5$ (West 2010) \\
\hline Michigan & Mich. COMP. LAWS ANN. $\S 211.7 \mathrm{~s}$ (West 2010) \\
\hline Mississippi & Miss. CODE ANN. § 27-31-1(d) (West 2012) \\
\hline Montana & MONT. CODE ANN. § 15-6-201(1)(b) (2019) \\
\hline Nevada & NEV. REV. STAT. ANN. $\S 361.125(1)(b)$ (LexisNexis 2016) \\
\hline New Hampshire & N.H. REV. STAT. § 72:23(III) (2012) \\
\hline New Jersey & N.J. STAT. ANN. § 54:4-3.6 (West 2017) \\
\hline New York & N.Y. REAL PROP. TAX LAW $\S 462$ (McKinney 2017) \\
\hline North Carolina & N.C. GEN. STAT. ANN. § 105-278.3(d)(1) (West 2018) \\
\hline North Dakota & N.D. CENT. CODE ANN. § 57-02-08(9)(a) (2018) \\
\hline Rhode Island & 44 R.I. GEN. LAWS ANN. § 44-3-3(a)(6) (2010) \\
\hline South Carolina & S.C. CODE ANN. $\S 12-37-220(A)(3)$ (Supp. 2019) \\
\hline Texas & TEX. TAX CODE ANN. $\S 11.20$ (West 2015) \\
\hline Vermont & VT. STAT. ANN. tit. 32, § 3832(2) (Supp. 2019) \\
\hline Virginia & VA. CODE ANN. § 58.1-3606(A)(2) (2017) \\
\hline Washington & WASH. REV. CODE ANN. $\S 84.36 .020(2)$ (a) (West 2018) \\
\hline West Virginia & W. VA. CODE ANN. § 11-3-9(a)(6) (LexisNexis 2020) \\
\hline Wisconsin & WIS. STAT. ANN. $\S 70.11(4)$ (West 2016) \\
\hline Wyoming & WYO. STAT. ANN. § 39-11-105(a)(vii)(A) (2019) \\
\hline
\end{tabular}


APPENDIX 2: NON-STATUTORILY-RECOGNIZED EXEMPTION FOR PARSONAGES

\begin{tabular}{|c|c|c|}
\hline State & $\begin{array}{c}\text { General Religious } \\
\text { Exemption }\end{array}$ & Judicial Application to Parsonages \\
\hline Delaware & $\begin{array}{l}\text { Del. Code. Ann. } \\
\text { tit. } 9, \S 8105(2011)\end{array}$ & $\begin{array}{c}\text { St. Stanislaus Kostka Church } \\
\text { v. Mayor of Wilmington, } \\
105 \text { A.2d 596, } 599 \text { (Del. Super. Ct. 1954), } \\
\text { aff'd sub nom. } \\
\text { Mayor of Wilmington } \\
\text { v. St. Stanislaus Kostka Church, } \\
108 \text { A.2d } 581 \text { (1954) }\end{array}$ \\
\hline Iowa & $\begin{array}{l}\text { Iowa Code Ann. } \\
\$ 427.1(8)(\mathrm{a}) \\
\text { (West } 2020)\end{array}$ & $\begin{array}{c}\text { Trinity Lutheran Church of Des Moines } \\
\text { v. Browner, } \\
255 \text { Iowa 197, 200-01 (1963) }\end{array}$ \\
\hline Louisiana & $\begin{array}{c}\text { La. Const., } \\
\text { art. VII, } \S 21(\mathrm{~B})(1)(\mathrm{a})(\mathrm{i})\end{array}$ & \\
\hline Minnesota & $\begin{array}{l}\text { Minn. Stat. Ann. } \\
\S 272.02 \text { subd. } 6 \\
\text { (West } 2017 \text { ) }\end{array}$ & $\begin{array}{l}\text { In re Collection of Delinquent Real Prop. } \\
\text { Taxes, } \\
530 \text { N.W.2d 200, } 203 \text { (Minn. 1995) }\end{array}$ \\
\hline Missouri & $\begin{array}{l}\text { Mo. Const. } \\
\text { art. } X, \S 6(1)\end{array}$ & $\begin{array}{c}\text { Bishop's Residence Co. v. Hudson, } \\
\text { 4 S.W. } 435,435 \text { (1887) }\end{array}$ \\
\hline Nebraska & $\begin{array}{l}\text { Neb. Rev. Stat. Ann. } \\
\$ 77-202(1)(d) \\
\text { (LexisNexis 2017) }\end{array}$ & $\begin{array}{l}\text { Neb. Ann. Conf. of United Methodist Church } \\
\text { v. Scotts Bluff Cty. Bd. of Equalization, } \\
499 \text { N.W.2d 543, } 548 \text { (1993) }\end{array}$ \\
\hline $\begin{array}{l}\text { New } \\
\text { Mexico }\end{array}$ & $\begin{array}{l}\text { N.M. Const. } \\
\text { art. VIII, } \S 3\end{array}$ & $\begin{array}{l}\text { N.M. Admin. Code 3.6.5.15(L)(2) } \\
\text { (as amended in 2001) }\end{array}$ \\
\hline Oklahoma & $\begin{array}{c}\text { Okla. Const. } \\
\text { art. X, } \S 6 \\
\end{array}$ & $\begin{array}{c}\text { Immanuel Baptist Church v. Glass, } \\
497 \text { P.2d 757, } 760 \text { (Okla. 1972) }\end{array}$ \\
\hline $\begin{array}{l}\text { South } \\
\text { Dakota }\end{array}$ & $\begin{array}{c}\text { S.D. Codified Laws } \\
\S 10-4-9 \text { (Supp. 2020) }\end{array}$ & $\begin{array}{c}\text { State v. Erickson, } \\
182 \text { N.W. } 315,319 \text { (S.D. 1921) }\end{array}$ \\
\hline
\end{tabular}


ApPendix 3: Parsonage EXeMPtion Depends On USE

\begin{tabular}{|c|c|c|}
\hline State & $\begin{array}{c}\text { General Religious } \\
\text { Exemption } \\
\end{array}$ & $\begin{array}{c}\text { Conditions for Application to } \\
\text { Parsonages } \\
\end{array}$ \\
\hline California & $\begin{array}{c}\text { CAL. REV. \& TAX. CODE } \\
\text { \& 214(a) } \\
\text { (West 2011) }\end{array}$ & $\begin{array}{l}\text { First United Methodist Church of Santa } \\
\text { Monica } \\
\text { v. Los Angeles Cnty., } \\
\text { 161 Cal. App. 3d 1091, 208 Cal. Rptr. 85, } \\
\text { 93 (Cal. Ct. App. 1984) }\end{array}$ \\
\hline Oregon & $\begin{array}{l}\text { OR. REV. STAT. ANN. } \\
\S 307.140(1)(2017)\end{array}$ & $\begin{array}{l}\text { Washington Cnty. Assessor } \\
\text { v. W. Beaverton Congregation of } \\
\text { Jehovah's Witnesses, Inc., } \\
18 \text { Or. Tax } 409,417-18(2006)\end{array}$ \\
\hline Tennessee & $\begin{array}{l}\text { TENN. CODE ANN. } \S 67-5- \\
\text { 212(a)(1) (2018) }\end{array}$ & $\begin{array}{c}\text { Blackwood Bros. Evangelistic Ass'n } \\
\text { v. State Bd. of Equalization, } \\
\text { 614 S.W.2d } 364,366 \\
\text { (Tenn. Ct. App. 1980) }\end{array}$ \\
\hline
\end{tabular}

APPENDIX 4: No PROPERTY TAX EXEMPTION FOR PARSONAGES

\begin{tabular}{|c|c|c|}
\hline State & $\begin{array}{c}\text { General Religious } \\
\text { Exemption }\end{array}$ & Denial of Application to Parsonages \\
\hline Ohio & $\begin{array}{c}\text { OHIO REV. CODE ANN. } \\
\$ 5709.07(\mathrm{~A})(2)-(3) \\
\text { (LexisNexis 2019) }\end{array}$ & $\begin{array}{c}\text { Grace Cathedral, Inc. v. Testa, } \\
36 \text { N.E.3d 136, } 141 \text { (Ohio 2015) }\end{array}$ \\
\hline Pennsylvania & $\begin{array}{l}72 \text { PA. STAT. ANN. } \\
\$ 5020-204(a)(1) \\
\quad(\text { West 2013) }\end{array}$ & $\begin{array}{c}\text { Connellsville Street Church of Christ } \\
\text { v. Fayette Cnty. Bd. of Assessment Appeals, } \\
838 \text { A.2d 848, } 853 \text { (Pa. Commw. Ct. 2003) }\end{array}$ \\
\hline Utah & $\begin{array}{l}\text { UTAH CONST. } \\
\text { art. XIII, } \S 3(1)(f)\end{array}$ & $\begin{array}{l}\text { Salt Lake Cty. v. Tax Comm'n } \\
\text { ex rel. Good Shepherd Lutheran Church, } \\
548 \text { P.2d 630,631 (Utah 1976) }\end{array}$ \\
\hline
\end{tabular}

ApPendix 5: No Judicial Guidance on Treatment of Parsonages

\begin{tabular}{c|c} 
State & $\begin{array}{c}\text { General Religious Property Tax } \\
\text { Exemption }\end{array}$ \\
\hline Alabama & $\begin{array}{c}\text { ALA. CODE } \\
\S 40-9-1(1)(\text { LexisNexis } 2011)\end{array}$ \\
\hline Arizona & $\begin{array}{c}\text { ARIZ. REV. STAT. ANN. } \\
\S 42-11109(\mathrm{~A})(2018)\end{array}$ \\
\hline Colorado & $\begin{array}{c}\text { COLO. REV. STAT. ANN. } \\
\S 39-3-106(\text { West } 2019)\end{array}$ \\
\hline Kentucky & KY. CONST. $\S 170$
\end{tabular}

